\title{
FREEDOM OF SPEECH, CYBERSPACE, HARASSMENT LAW, AND THE CLINTON ADMINISTRATION
}

\author{
EUGENE VOLOKH*
}

\section{INTRODUCTION}

During the height of the Clinton-Lewinsky scandal, many lawyer pundits talked about impeachment. Some talked about independent counsels and separation of powers. Some talked about the criminal law of perjury, or the rules of evidence, or whether indecent exposure constituted sexual harassment.

A few experts, though, focused on a more practical issue: Saying certain things about the scandal, they advised people, might be legally punishable. "Be careful what you say," one headline warned, when you discuss "the Starr report and Clinton/Lewinsky matter" in certain ways. " "Talking about Clinton? Tread carefully," says another, pointing out the risk of "a lawsuit from an offended coworker." Such discussions "ought to be avoided" because of the risk of legal liability." "[I]t's best to choose carefully who you share your remarks, your jokes, with .... 'Attorneys warn us about [legal liability] ....' Office humor in particular 'is always quicksand'...." "There's no right [to make certain state-

Copyright (C) 2000 by Eugene Volokh

This article is also available at http://www.law.duke.edu/journals/63LCPVolokh.

* Professor of Law, UCLA (volokh@law.ucla.edu).

Many thanks to Jeff Rosen for his comments and to the UCLA School of Law reference librarians for their tremendous research help.

1. Diane Sears Campbell, Don't Cause a Scandal-Be Careful What You Say, ORLANDo SENTINEL, Sept. 23, 1998, at E4 ("Sexually explicit discussions, comments, jokes and gestures that could be perceived by a co-worker to be offensive can lead to a harassment claim, attorneys say. Here the word from John Finnigan and Aaron Zandy, Orlando attorneys: 'Workplace discussions that are sexually graphic or explicit about the Starr report and Clinton/Lewinsky matter are no different than any other workplace discussions of a sexual nature that are now inappropriate in the workplace and ought to be avoided."').

2. Hollis L. Engley, Talking About Clinton? Tread Carefully; Chatter too much about sexual matters and risk a complaint or a lawsuit from an offended co-worker, DES MOINES REGISTER, Jan. 29, 1998, at 1 ("Should we be talking at the workplace about the president's sexual preferences? And if so, how? Very carefully, say the experts.... [T]alk too much about sexual matters of any kind and risk a complaint or even a lawsuit from an offended co-worker."); see also Julie Waresh, Can We Talk? Offices Full of Jokes on "The Affair", PALM BEACH POST, Sept. 20, 1998, at 1F ("While the Starr report may have created an atmosphere that encourages lewd remarks and innuendo, sexual harassment experts say workers should be careful.").

3. Engley, supra note 2.

4. Leslie Taylor, The Starr Report and Office Politics, RoAnOKE Times \& WORLD News, Sept. 24, 1998, at C1 (quoting Gloria Elliott, a Roanoke business consultant). 
ments about the Clinton/Lewinsky affair] just because it's a public issue." "We had quite a few clients calling us when Lewinsky jokes... were making the rounds." "People think that if they hear something on TV or the radio they can say it at work [without fear of legal liability]. But that of course is not the case."

5. L.M. Sixel, Scandal Sapping Sensitivity at Office, Houston CHRON., Sept. 18, 1998, at 1 ("When exactly does the rehashing of cigar sex and hallway encounters rise to the level of a hostile work environment? ... That hinges on whether a reasonable person would find the conversation offensive [and pervasive enough], said Gerald Holtzman, [a Houston] employment lawyer .... There's no right to talk offensively just because it's a public issue."); Geeta Sharma-Jensen, Scandal Heats up Workplace Banter, MiLWAUKEE J.-SENTINEL, Feb. 9, 1998, at 1 ("Managers must recognize that some workers may object to discussion of sexually charged politics in the workplace, said John Patzke, [an employment lawyer]. 'They still need to be sensitive to those objections and enforce their sexual harassment policies, despite the political relevance,' he said.").

6. Yochi Dreazen, Talking About Sex; Where Do You Draw the Line in the Office?, Houston Chron., July 26, 1998, at A2 ("For Monica Ballard, whose Santa Monica-based Parallax Education company counts Burger King, Kraft Foods and Exxon among its clients, the tension between a popular culture that encourages talk about sex and a workplace mentality that seeks to restrict it was driven home in the first days of the Lewinsky scandal. 'We had quite a few clients calling us when Lewinsky jokes, some of which were quite graphic, were making the rounds,' she said. 'People think that if they hear something on TV or the radio they can say it at work. But that of course is not the case."').

7. See id.; see also Carol Smith, Sexual Harassment Arena Is Broadened, Binding Employers, SEATtLE POST-INTELligenCER, Oct. 30, 1998, at B1 ("[I]s it sexual harassment when employees are sitting around talking about the Starr Report and making jokes about cigars? The answer is, 'It depends."').

Consider also the recent advice by employment experts that tolerating "blonde jokes" could expose employers to legal punishment. See, e.g., Genevieve Buck, Sexual Harassment Rulings Hit Close to Home, CHI. TRIB., July 17, 1998, at C5 ("Get an anti-harassment policy in place. Specify what conduct is unacceptable, including posters, pictures, gestures, blond jokes, language, whatever.”); Richard A. Fishel, Medicine \& The Law: "Employee Sues Doctor"-Sexual Harassment $<$ http://www.physiciannet.com/med\&law.html> ("Ask yourself these questions ... Have I told a particularly funny sexual joke or one of those current dumb blonde jokes? ... 'Yes' answers to any of the above could put you at risk of sexual harassment charges. ... Here are some guidelines that can reduce the risk of sexual harassment in your work place.... Don't allow offensive jokes ...."); Andrea Kay, Online Jokes Can Lead to Serious Problems; Offensive Messages Might Become Basis of Lawsuits, CINCINNATI ENQUiRER, Sept. 14, 1998, at B15 ("Have you heard the one about the gay trucker? Or how about the dumb blond who hangs out with smart guys? .... Those, or one of the other so-called harmless jokes circulating on your company network, could be the impetus for a nasty harassment suit."); Michael Stetz, E-Mail Humor in Eye of Beholder, S.D. UNION-TrIB., Nov. 29, 1998, at A1 ("Dumb blonde jokes? Stupid men jokes? Bill and Monica jokes? ... This can be treacherous ground. Companies are being sued because of sexually explicit or racially offensive messages that have gone through their computer e-mail systems.... Lawsuits are brewing over offensive material transmitted through e-mail messages ...."); Carol Teegardin, How to Deal with Sexual Harassment, THE RECORD (BERGEN COUNTY), Oct. 26, 1998, at H6 (interview with Sue Ellen Eisenberg, a sexual harassment lawyer who had earlier participated in drafting the federal sexual harassment guidelines) (giving as example of sexual harassment "[d]umb-blonde jokes, [which] characterize women as being stupid and inferior, and it's all cloaked in humor"); $c f$. Spaulding v. West, 1998 WL 745717 (EEOC Oct. 16) (describing harassment claim based on three alleged incidents, including the telling of blonde jokes, concluding that these three incidents in five years weren't severe or pervasive enough for a harassment claim, but stressing that the employer "took immediate action to prevent the reoccur[e]nce of and to mitigate the impact of the alleged incidents," and that the EEOC "does not condone the several incidents cited by appellant”); Rick Anderson, “No Blonde Jokes,” SEATTLE WEEKLY, June 3-9, 1999, at 7 (describing harassment complaints against a police detective based in part on his having made blonde jokes, and quoting a commander saying that "I don't think it [a dumb-blonde joke, for one] is appropriate no matter what it is ... . We are getting to a point now that if you are smart, you don't tell jokes."). 
What body of law, one might ask, would suppress jokes about the President or discussion of the Starr Report? Not the most publicized free speech restriction of the Clinton years, the Communications Decency Act of 1996, ${ }^{8}$ which was struck down 9-0 by the Supreme Court. ${ }^{9}$

Rather, this remarkable speech restriction is hostile environment harassment law. Under this doctrine, speech can lead to massive liability if it is "severe or pervasive" enough to create a "hostile, abusive, or offensive work environment" for the plaintiff and for a reasonable person based on the person's race, religion, sex, national origin, disability, age, veteran status, and in some jurisdictions a variety of other attributes. ${ }^{10}$ And this rather vague and broad test has long been interpreted to cover not just face-to-face slurs or repeated indecent propositions, but also sexually themed jokes and discussions, even ones that aren't about co-workers or directed at particular co-workers. ${ }^{11}$ The prudent employer is wise to restrict speech like this, whether it is about President Clinton, Monica Lewinsky, Kenneth Starr, or anyone else-not just because of

Lewinsky, of course, is a brunette, but the core of many blonde jokes-blondes' supposed promiscuity and stupidity-was also the core of many Lewinsky jokes.

8. See Pub. L. No. 104-104, 110 Stat. 133-145 (codified as amended at 47 U.S.C. § 223(a), (d) (1934)).

9. See Reno v. American Civil Liberties Union, 521 U.S. 844 (1997). I refer here to the most discussed and most significant part of the CDA, which barred the public posting of indecent material in places to which minors had access. Another portion, which focused on the distribution of indecent material to specific minors, was struck down 7-2; a third provision, which dealt with e-mail sent to particular people in order to annoy them, wasn't challenged in the Reno v. ACLU litigation.

10. See <http://www.law.ucla.edu/faculty/volokh/harass/breadth.htm\#IA >, which contains an updated version of Eugene Volokh, What Speech Does Workplace Harassment Law Restrict?, 85 GEO. L.J. 627, 628 (1997).

11. See, e.g., Dernovich v. City of Great Falls, Mont. Hum. Rts. Comm'n No. 9401006004 (Nov. 28, 1995); Cardin v. Via Tropical Fruits, Inc., No. 88-14201, 1993 U.S. Dist. LEXIS 16302, at *24-25 \& n.4 (S.D. Fla. July 9); U.S. Dep't of Labor, Sexual Harassment: Know Your Rights (1994) (defining sexual harassment to include situations where "[s]omeone made sexual jokes or said sexual things that you didn't like"); Mont. Hum. Rts. Comm'n, Model Equal Employment Opportunity Policy: A Guide for Employers (no date) ("Examples of prohibited sexual harassment include, but are not limited to: ... Repeated sexual jokes, innuendoes, or comments ...."); Margaret Hart Edwards, Sexual Harassment: Definition, Prevention, and Treatment, C989 ALI-ABA 215 (Mar. 26, 1995) ("Some examples of behaviors that may be sexual harassment are:... Coffee mugs with sexual pictures or words on them ... . Telling dirty jokes or stories ...."); When a Joke is a Crime, CHRISTIAN SCI. MONITOR, Mar. 2, 1998, at B5 ("repeated instances" of "using e-mail to send sexual jokes to other staff members" could be harassment; so could "a male and a female co-worker repeatedly talk[ing] about their respective sexual affairs and relationships during break around the office coffee pot ... if a passerby finds it offensive"); Is a Wink as Bad as a Nod?, BOSTON HERALD, Apr. 5, 1998, at 8 ("DON'T EVER (the clear cases)... The following are likely to be interpreted as sexual harassment, according to the Quincy law firm of Murphy, Hesse, Toomey and Lehane ... Sexual epithets or jokes ... Displaying sexually suggestive objects, pictures or cartoons"); Stephen Henderson, America Re-Examines the Issues, CHI. TRIB., May 23, 1996, at 1 ("[T]elling dirty jokes in the presence of a female employee [even when the jokes are not directed at her]... 'is an example of 'hostile environment' sexual harassment.... The legal thinking behind 'hostile environment' harassment is that people should be able to arrive at work, do their job and go home without having to hear jokes, stories or comments of a sexual nature." (quoting Monica Ballard, president of a firm that teaches employees about sexual harassment and the author of six textbooks on prevention of sexual harassment)). See generally $<\mathrm{http}$ ///www.law.ucla.edu/faculty/volokh/harass/breadth.htm\#JOKES $>$, discussing this further and citing more examples. 
professionalism concerns (which some employers might care more about and others less), but because of the risk that this speech will be found to be legally punishable. $^{12}$

I was asked to participate in this symposium by discussing the Clinton Administration and free speech in cyberspace, and I will do so. But inquiring into the Clinton Administration's role in cyberspace speech regulation may be asking the wrong question. I'm not sure that particular Administrations generally have much of a direct impact on free speech law (as opposed to the indirect impact, often not seen for decades, flowing from the decisions of the judges they appoint). The Clinton Administration, for instance, has mostly confronted free speech law incidentally and sporadically; the high-profile direct attempts to seriously restrict speech, such as the $\mathrm{CDA}$, have largely come from Congress. ${ }^{13}$

Moreover, the words "in cyberspace" in the phrase "restrictions on free speech in cyberspace" are generally, in my view, not terribly significant; the medium by and large does not and should not affect the protection-or lack of protection-given to the content. The CDA and the Child Online Protection $\mathrm{Act}^{14}$ do pose some interesting cyberspace-specific questions, but even with these laws, most of the important issues are broader free speech questions: May speech be restricted if the restriction is in fact necessary to effectively serve a compelling government interest? What burdens may be placed on adults in order to shield children . $^{15}$

Instead of directly confronting Clinton, free speech, and cyberspace, I'd therefore like to instead present four cyberspace speech controversies that involve what I think is the most interesting modern body of speech restrictions: hostile environment harassment law. And these examples, I think, will help illustrate three things.

12. Some have claimed that these examples are just overreactions or "bizarre ... misapplications" of otherwise sound harassment law principles. See, e.g., Deborah Epstein, Can a "Dumb Ass Woman" Achieve Equality in the Workplace? Running the Gauntlet of Hostile Environment Harassing Speech, 84 GEO. L.J. 399, 418 (1996). But given (1) a standard as vague as "severe or pervasive enough to create a hostile, abusive, or offensive work environment for the plaintiff and a reasonable person," (2) the many statements by courts and government agencies explaining that sexually themed jokes can form the basis of a harassment lawsuit, and (3) the dozens of statements to this effect from independent employment experts, it is eminently plausible that such speech may lead to liability, and that reasonable and prudent employers will want to restrict it to avoid the risk of liability. For a more developed discussion, see sources cited supra note 10.

In the words of Justice Brennan, "[i]f there is an internal tension between proscription and protection in the statute, we cannot assume that, in its subsequent enforcement, ambiguities will be resolved in favor of adequate protection of First Amendment rights." NAACP v. Button, 371 U.S. 415, 438 (1963).

13. Proposals for restricting speech in the name of protecting intellectual property are a noteworthy exception; as Jamie Boyle has pointed out, this Administration has proposed quite a few of these, though Congress has also independently gotten into the act. See generally James Boyle, The First Amendment and Cyberspace: The Clinton Years, 63 LAW \& CONTEMP. PROBS. 337 (Winter/Spring 2000).

14. 47 U.S.C. $\$ 231$.

15. See generally Eugene Volokh, Freedom of Speech, Shielding Children, and Transcending Balancing, 1997 SUP. CT. REV. 141. 
First, in most of the controversies, the result should largely be driven not by the medium, but by the relatively medium-independent underlying free speech principles. Second, the Clinton Administration's role in these areas has been comparatively slight: The Administration has been involved primarily as a consumer of existing law rather than as a producer of new law. ${ }^{16}$ And third, each of the controversies shows that there is considerable truth to the much-maligned concept of the slippery slope. Speech restrictions generally do not spring fullgrown from the head of Leviathan; rather, especially in a system built on precedent and on litigation by many plaintiffs in many courts, they accrete over time, each victory for restriction laying the groundwork for broader restrictions in the future. This tendency can, of course, be resisted-but it ought not be ignored.

\section{II}

\section{The Hidden COMMUNiCATIONS DECENCY ACT}

In 1997, the Equal Employment Opportunity Commission filed a workplace harassment lawsuit, which is still pending, ${ }^{17}$ against the Federal Home Loan Mortgage Corporation, also known as Freddie Mac. ${ }^{18}$ The lawsuit alleged various misconduct by Freddie Mac employees, including the following item: Some employees allegedly sent to a department-wide distribution list "derogatory electronic messages regarding "ebonics" - a list of jokes mocking the black dialect, seemingly a response to the then-current Oakland School Board proposal to treat "ebonics" as a separate language. ${ }^{19}$ This, the EEOC claimed, contributed to a racially hostile work environment, and it was thus illegal for Freddie Mac to tolerate such speech; Freddie Mac had a duty to "take prompt and effective remedial action to eradicate" it. $^{20}$

Nor was this an isolated incident. In 1997, for instance, R.R. Donnelly, Morgan Stanley, and Citibank were all sued based in part on offensive jokes sent through e-mail. Newspaper articles reporting on these lawsuits featured headlines such as "Defusing the E-Mail Time Bomb ... Establish Firm Workplace Rules to Prevent Discrimination Suits," "E-Mail Humor: Punch Lines Can Carry Price; Jokes Open Employers To Discrimination Suits," and "Firms Get Sobering Message; E-mail Abuses May Leave Them Liable." ${ }^{21}$ In a less widely reported case,

16. Primarily, but not entirely: As Jeff Rosen points out, the Clinton Administration did support important evidentiary changes that made some harassment claims easier to bring. JEFFREY ROSEN, THE UNWANTED GAZE 128-58 (2000).

17. On Sept. 10, 1999, Arlene Shadoan, the EEOC attorney in the case, told Kevin Gerson of the UCLA School of Law library that the EEOC and Freddie Mac were still in conciliation, hoping to resolve the case without going to trial.

18. Complaint in EEOC v. Federal Home Loan Mortgage Corp., civ. no. 97-1157-A, at 3, 4 (E.D. Va. July 24, 1997)

19. Id.; see also John Leo, Ebonics? No Thonics!, U.S. NEWS \& WORLD REP., Jan. 20, 1997, at 20.

20. Complaint in EEOC v. Federal Home Loan Mortgage Corp., civ. no. 97-1157-A, at 3, 4 (E.D. Va. July 24, 1997).

21. See Matthew H. Meade, Defusing the E-Mail Time Bomb; E-Mail is Mail: Establish Firm Workplace Rules to Prevent Discrimination Suits, PITTSBurgh Post-GAZETte, Apr. 25, 1997, at A-17; see also 
the New Jersey Office of Administrative Law recently found a single incident of a long joke list being forwarded by e-mail to the whole department to be "sexual harassment," creating an "offensive work environment." The judge "f[ou]nd [that] the 'jokes' degrade, shame, humiliate, defame and dishonor men and women based upon their gender, sexual preference, religion, skin pigmentation and national and ethnic origin" and are thus illegal. ${ }^{22}$ Similarly, in Trout v. City of Akron, a jury awarded a plaintiff $\$ 265,000$ based in part on coworkers viewing pornographic material on their computers. ${ }^{23}$

Most of the other allegations in the Freddie Mac lawsuit involved offensive conduct that is entitled to no First Amendment protection; the EEOC's case is not entirely based on protected speech, although some harassment cases have in fact been so based. ${ }^{24}$ Nonetheless, as the Supreme Court has held, judgments that are based even in part on constitutionally protected speech must comport with First Amendment principles ${ }^{25}$ - and the experience of harassment law makes clear why this settled doctrine is eminently sound.

Imagine how a cautious employer would react to a decision imposing liability in the Freddie Mac harassment case or even to the EEOC's decision to sue Freddie Mac. Though in theory individual offensive political statements are not actionable under harassment law unless they are aggregated with at least some other speech or conduct, in practice the employer can't just tell its employees, "It's fine for you to e-mail political statements that some may find racially, religiously,

Michael Rapoport, Firms Get Sobering Message; E-mail Abuses May Leave Them Liable, HousTON Chron., Feb. 23, 1997, Business sec., at 1; Michelle Singletary, E-Mail Humor: Punch Lines Can Carry Price; Jokes Open Employers to Discrimination Suits, WASH. POST, Mar. 18, 1997, at A01.

22. Olivant v. Department of Environmental Protection, 1999 WL 430770 (N.J. Admin. Apr. 12). The administrative law judge specifically held that the speech fit the legal definition of generally actionable sexual harassment, citing N.J. ADMIN. CODE § 4A:7-11, which is directly parallel to the general sexual harassment regulations governing speech in all workplaces, public and private. Though this case involved the government acting as employer (where I agree the government has broad power over offensive speech by its employees), the holding that the speech constituted "sexual harassment" under the general definition would be applicable to private workplaces as well as public ones. See also Board of Ed. v. Grundfest, $2000 \mathrm{WL}$ 890869 (N.J. Admin. Mar. 29) ("Grundfest's intentional access of pornography at the school created an offensive working environment. Compare [Olivant] (appellants' distribution of sexist humor over electronic-mail system constituted sexual harassment ....").

23. See Complaint, Trout v. City of Akron, No. CV-97-115879 (filed Nov. 17, 1997); Verdict, id. (Dec. 15, 1998); Internet Pornography and Harassment, Trout v. City of Akron, 1999 No. 2 DISC. L. UPDATE 7. The complaint was also based in part on circulation of pornographic magazines, sexual jokes, and crude personal remarks; but, as I discuss below, even if some of this speech was constitutionally unprotected, the First Amendment is implicated when a judgment is based even in part on protected speech.

24. See, e.g., Brown Transp. Corp. v. Commonwealth, 578 A.2d 555, 562 (Pa. Commw. Ct. 1990); EEOC Letter of Determination, Ozawa v. Hyster Co., Charge No. 380863519 (Dec. 15, 1987) and Complaint, EEOC v. Hyster Co., No. 88-930-DA (D. Or. filed Aug. 15, 1988), discussed in Volokh, supra note 10, at 632 n.17; Bowman v. Heller, No. CIV.A. 90-3269, 1993 WL 761159, at *2, *13 (Mass. Super. Ct. July 9), aff'd in part on other grounds, vacated in part, 651 N.E. 2 d 369 (Mass. 1995); Dernovich v. City of Great Falls, Mont. Hum. Rts. Comm'n No. 9401006004 (Nov. 28, 1995).

25. See NAACP v. Claiborne Hardware Co., 458 U.S. 886, 915 (1982); Street v. New York, 394 U.S. 576, 590 (1969); Mount Healthy City School District Bd. of Educ. v. Doyle, 429 U.S. 274, 287, 28384 (1977) (holding that the First Amendment is violated whenever protected speech makes a difference in deciding a speaker's fate). 
or sexually offensive, unless there have been other incidents in which other people have also been mistreating the offended worker in other ways-incidents of which you, the employee, might not even be aware." So long as constitutionally protected speech can be part of a hostile environment claim, the cautious employer must restrict each individual instance of such speech: After all, this particular statement might make the difference between a legally permissible, nonhostile environment, and an illegal hostile environment. The employer must say, "Do not circulate any material, even isolated items, that anyone might find racially, religiously, or sexually offensive, since put together such material may lead to liability."

This is exactly what employment experts are counseling employers to do. For instance, according to an article called Employers Need to Establish Internet Policies, "avoiding potential sex-harassment liability is a major incentive for companies to establish Internet policies." 26 To prevent "incurring liability under state and federal discrimination laws," businesses should have written policies that bar, among other things, "download[ing] pornographic picture[s]"- not just distributing them but even simply downloading them-and sending "messages with derogatory or inflammatory remarks about an individual or group's race, religion, national origin, physical attributes, or sexual preference." ${ }^{27}$ The advice is, of

26. Mark A. Cohen, Employers Need to Establish Internet Policies, MiCH. LAWYERS WeEKLY, Apr. 13, 1998, at 1; A Model Internet Policy for Companies, MICH. LAWYERS WEEKLY, Apr. 13, 1998, at 28.

27. Cohen, supra note 26; A Model Internet Policy for Companies, supra note 26; see also Boss May Lurk as You Surf the Web, L.A. TIMES, Aug. 9, 1999, at E3 ("When workers circulate lewd e-mail or Xrated Web sites, it opens [businesses] to multimillion-dollar harassment lawsuits. The discovery of an offcolor electronic message at the St. Louis investment firm of Edward Jones in April forced the company to dismiss 19 employees and to reprimand 41 others."); More Firms Monitoring E-Mail, PATRIOT LEDGER (Quincy, Mass.), Mar. 4, 1999, at 8 ("Do you like sending dirty jokes by E-mail? Don't try sending one to Fidelity Investments employees. The Boston-based company last month disciplined an unspecified number of employees for abusing their E-mail privileges and access to company computers.... There's a good reason [for employer monitoring of offensive e-mail]: A recent string of legal cases has underscored E-mail's power as a key prosecution weapon, raising concern among employers that offensive messages could become a legal hot potato down the road.... Further dogging corporate legal departments, twin Supreme Court rulings last spring made it easier for employees to sue for sexual harassment in the workplace ...."); Paul van Slambrouck, E-Mail Culture Goes to Court, CHRISTIAN SCI. MONITOR, Oct. 23, 1998, at 1 ("Company personnel offices are increasingly dealing with the problems that arise from e-mail. An offcolor joke, uninvited or seen by others, can constitute sexual harassment if the company doesn't take action."); see also Matt Roush, E-Mail Can Spell Trouble, So Think Before You Hit "Send," CRAIN'S DETROIT BUSINESS, Sept. 20, 1999, at 16 ("'E-mail . . can be used to buttress claims of hostile work environment in a sexual harassment case,' [said a partner at a Detroit law firm]. . . . [Employers' e-mail policies] should make it clear that hacking and spreading hate or pornography can be firing offenses."); Risk Managing the E-Mail Exposure, MANAGING RISK, May 1996 ("Sex-Related E-Mail: Harassment Suits Waiting to Happen ... . Sample E-Mail Policy ... . Be especially careful to avoid messages that may be interpreted as sexual harassment."); Carlene Hempel, You Are Being Watched, RALEIGH NEWS \& OBSERVER, June 21, 1998, at E1 ("Porn left on screens can result in sexual harassment or hostile work environment suits."); Erica Roberts, The Lawyer's in the Mail, DATA COMM., Sept. 1, 1998 ("Here's a message for corporate networkers: Develop an effective e-mail policy or get a good lawyer. Better yet, do both. Companies are being held liable for offensive e-mail."); Companies Tighten Monitoring of Worker Web Use, TUlSA WORLD, Nov. 22, 1998 ("The possibility of lengthy and expensive lawsuits stemming from claims of sexual harassment, discrimination and hostile-workplace environments has many firms rushing to put ironclad restrictions in place before a problem comes to light. . . ' The equation I would look at if I had to decide how to manage these resources is this: One sexual-harassment claim can cost millions' [quoting Eric Goldman, a leading cyberspace lawyer]."); Sherry L. Katz-Crank, Avoid Misuse of 
course, not to "bar downloading pornographic pictures and sending messages with derogatory remarks when they are severe or pervasive enough to create a hostile, abusive, or offensive work environment"; rather, the advice is to bar any such downloading and any such messages. ${ }^{28}$

Likewise, an article called Preventing Internet-Based Sexual Harassment in the Workplace, published in a legal newspaper and aimed at employment lawyers, pointed out the risk of liability flowing from the aggregate of various employees' speech:

[I]f sexual and sexist communications were allowed to flourish in the workplace, unchecked and uncensored, an employer may be liable for sexual harassment.... With the increasing popularity of the Internet in the workplace, employers face new risks of a hostile environment developing right under their electronic noses. One employee may be downloading pornographic pictures and using them as screen savers, or printing them at his printer, often located in a common area. Another may be receiving and distributing sex jokes through the employer's e-mail system. Yet another may be spending time surfing the X-rated territory of the World Wide Web, with his monitor open to be seen by passers-by.

For the benefit of its employees as well as to avoid liability, an employer should attempt to prevent the creation of a hostile environment. First, the employer can choose to use technology against technology. The same software sold to parents to block children's access to sex-related Web sites can be used by employers to control its employees' activities. ${ }^{29}$

Technology and Potential Lawsuits, Mich. LAwYers WeEkLy, June 22, 1998, at B2; Diana Kunde, Pushing the Envelope: E-Mail Can Be Trouble, Hous. CHRON., July 31, 1998, at 5; Emily Madoff, EMail's Role in Hostile Work Environment, N.Y.L.J., Aug. 23, 1999, at S6; Richard Raysman \& Peter Brown, Corporate Internet, Intranet and E-Mail Policies, N.Y.L.J., June 9, 1998, at 3; Jerome R. Stockfisch, Danger of E-Mail Is Exponential, TAMPA TRIB., May 8, 2000, at 5; Carol Tice, You've Got EMail-And a Lawsuit on Your Hands, NAT'L HOME CENTER News, Oct. 26, 1998, at 30. I've seen at least a hundred articles giving such advice.

28. See, e.g., Sample E-Mail Policy, 14 EMPLOY. CoORdinATOR II PM-10,133 (available on WESTLAW) ("Sample E-mail Policy.... Anti-harassment policies applicable. Company policies prohibiting sexual or other harassment are applicable to E-mail and voice mail systems. Messages that contain foul, inappropriate, or offensive language, or those containing racial or ethnic slurs, or sexual innuendo, are prohibited."); Companies Need Policies to Govern Computer Use, FLORIDA TIMESUNION (Jacksonville), May 1, 2000, at FB-11 ("[Employment attorney Alisa] Arnoff explained: 'Education is the key to reducing exposure for liability for sexual harassment.' She suggests disseminating a written policy that includes the following: ... E-mail communications that contain harassing, discriminatory, obscene, sexual or demeaning content are prohibited."); Judith N. Mottl, IT's Newest Role: Web Watchdog, INTERNETWEEK, June 1, 1998 (““[S]ending dirty E-mail or explicit graphics from a Web site can pose sexual harassment liability .... While most cases involving E-mail or Internet-related offenses rarely go to trial, it still costs a company thousands of dollars and time, which could have been avoided with a preventative approach."') (quoting lawyer Ruth Hill Bro); Sharon Machlis, Employers: State Policies, Monitor Internet Use, COMPUTERWORLD, July 20, 1998, at 20 ("[H]ow much trouble can a company get into if employees look at pornographic or racist Web sites on the job? Whenever that happens, the employer faces a potential lawsuit from offended colleagues, who can accuse the company of fostering a hostile work environment ....").

29. Hao-Nhien Vu, Preventing Internet-Based Sexual Harassment in the Workplace, L.A. DAILY J., Oct. 3, 1997, at 5; see also Cheryl Blackwell Bryson \& Michelle Day, Workplace Surveillance Poses Legal, Ethical Issues, NAT'L L.J., Jan. 11, 1999, at B8 (saying that the Morgan Stanley lawsuits "may have been more easily resolved had the company monitored its e-mail system, removed 'offensive' material and disciplined employees for circulating these jokes"). 
The suggestion that filters are needed to avoid liability appears to have become conventional wisdom. A USA Today article, for instance, concludes that, "In this new hyper-technical world, companies have but one easy call: Block sex Web sites. They have no business application, can spur sexual harassment suits and can be largely stopped with software costing $\$ 1,000$ to $\$ 5,000$ a year." ${ }^{30}$ Moreover, the suggestion includes not only Web filters, but also filters that censor internal e-mail in order to prevent e-mail containing legally punishable offensive speech. Praising this e-mail filter software, one securities firm official said that "it's a good idea.... There's already been three cases this year where someone sent out a joke about Ebonics or with an X-rated picture, and they got sued for having a hostile work environment. ${ }^{\prime 31}$ Likewise, a recent article titled Avoiding EMail Horror Stories; Policies and Filters the Best Defense pointed out that "many of the e-mail harassment cases could have been prevented if filters had been used because the e-mail would not have been sent." ${ }^{32}$

What's more, as employment experts are stressing, an employer may be liable even when offended employees merely hear about offensive speech that was said

30. Del Jones, Balancing Ethics and Technology, USA TODAY, Apr. 27, 1998, at 1A; Tim Wilson, Monitoring Employee Web Usage Is Desirable and Necessary, INTERNETWEEK, Aug. 11, 1997, at 28 ("Another reason for monitoring Web activity is legal liability.... [Y] our company may be held liable in a harassment suit because one employee was offended by a particular screensaver that another employee downloaded via the Net."); see also Jason Compton, Surfing on the Job; Is Personal Internet Use Really Bad for the Company?, CHI. TRIB., July 4, 1999, at C3 (quoting expert from George Mason University Institute of Computational Sciences and Informatics as saying that "sending inappropriate e-mails ... open[s] the organization up to civil liability for harassment").

31. See Shawn Willett, No Message Left Unread-Securities Software Acts as E-Mail Censor, COMPUTER RESELLER NEWS, July 14, 1997:

Several brokerage houses are beta testing software, dubbed Assentor, which analyzes Email messages for everything from U.S. Securities and Exchange Commission violations to political correctness. ...

[T] he product goes beyond looking for SEC violations. It also looks for possible sexual harassment or politically incorrect statements that might offend employees or customers....

"It's a good idea," said one official from a securities firm who asked to remain anony-

mous. "There's already been three cases this year where someone sent out a joke about

Ebonics or with an X-rated picture, and they got sued for having a hostile work environment."

See also Lee Copeland, VAR Helps Companies Survive the Age of E-Lawsuits, COMPUTER RESELLER News, Mar. 22, 1999; Anti-Harassment Software To Be Unveiled Today, NEwsBYTES, July 27, 1998; Sabrina Jones, Some Don't Get the Message, RAleigh News \& OBSERVER, July 24, 1999, at D1 ("More employers are beginning to scan the content of e-mails to filter out profanity, pornography, ethnic jokes and other blue language that could land a company in court."); Diana Kunde, Watched Words, DALLAS MORNING NEWS, July 22, 1998, at 1D (saying that "[f]irms worried about lawsuits and armed with sophisticated surveillance tools are monitoring employee e-mail," and citing e-mail hostile environment harassment cases as the reasons); Paul McNamara, Keeping an Eye on E-Mail, NETWORK WORLD, Oct. 5, 1998, at 80 ("[E]mployers increasingly are using e-mail surveillance software to guard against sexual harassment lawsuits and the loss of trade secrets .... [E]mployees caught red-handed by e-mail filters can and do lose their jobs, as bosses increasingly fear being accused of fostering a hostile work environment.").

32. Wendy R. Leibowitz, Avoiding E-Mail Horror Stories: Policies and Filters the Best Defense, N.Y. L.J., Dec. 15, 1998, at 5 (quoting information technology lawyer Michael R. Overly). 
only to consenting listeners. ${ }^{33}$ Thus, an article, entitled Downloading Liability: Employers Could Face Harassment Claims Arising from Internet Use, points out:

[B]y simply "surfing" the net employees or students can be creating an uncomfortable and hostile environment for their colleagues. This can occur whether sexually-oriented material is accidentally seen or deliberately pointed out.

Esther Nevarez, a sex-harassment educator for the New Jersey Division on Civil Rights, says that even if the employee is not directly exposed to the material, if others are sitting around watching it and laughing, etc., this "affects the esprit de corps in an office because it eliminates certain groups of people from participating." ...

To avoid liability employers must take the necessary steps to prevent sexual harassment. These steps should include a strong management directive clearly forbidding it and regulating the use of computer equipment....

Although a school [in context, referring to colleges and universities] by its very nature must provide for the guarantees of free speech as to classroom expression and assignment, the use of computers, [including] access to the Internet in open computer labs, should be appropriately regulated to avoid a hostile environment for offended students.

Not to take such preventive actions at the work place or school is to place the employer or school at risk. ${ }^{34}$

33. Consider Schwapp v. Town of Avon, a Second Circuit case holding that "twelve incidents of racially derogatory comments and acts" during a more than 20-month period were enough for a harassment claim, even though only four of the incidents occurred in the plaintiff's presence. "The district court," the Circuit held, "erred in failing to consider the eight... incidents that did not occur in Schwapp's presence," one of which was "made before Schwapp was hired." "[T]he fact that a plaintiff learns second-hand of a racially derogatory comment or joke by a fellow employee or supervisor also can impact the work environment ...." Schwapp v. Town of Avon, 118 F.3d 106, 108, 111-12 (2d Cir. 1997); see Barbetta v. Chemlawn Services Corp., 669 F. Supp. 569, 572 (W.D.N.Y. 1987); Sims v. Montgomery County Comm'n, 766 F. Supp. 1052 (M.D. Ala. 1990):

The department argues that [some uses of the word "nigger"] ... were made between white officers only. This argument not only misses the point, it reflects a total insensitivity to just how demeaning and insulting the term "nigger" is ... when black officers hear second-hand that a white officer whom they know and should respect has used the term on the job. Indeed, with this argument, the department fails to appreciate that racial harassment in the department can never be adequately redressed until all officers, in both their private and public comments at work, come to denounce the term.

But see Keenan v. Allan, 889 F. Supp. 1320, 1374-75, 1375 n.68 (E.D. Wash. 1995) (concluding that plaintiff "cannot rely on statements made to others, especially non-employees, to defeat summary judgment.... The Constitution is far better served by permitting unneighborliness, in the pursuit of free expression, than it is by outlawing it and rendering every working citizen mute."); Gleason v. Mesirow Financial, Inc., 1995 WL 561039, at *6 n.11 (N.D. Ill. Sept. 18) (noting that "hearing about comments directed toward others may still result in the plaintiff's experiencing a hostile work environment, [but] such secondhand observations have an emotional impact which ordinarily is less than the firsthand experiences of a direct target").

34. Jill Gerhardt-Powals (a member of the Computer Science and Information Systems Program at the Richard Stockton College of New Jersey) \& Matthew H. Powals (a New Jersey municipal court judge), Downloading Liability: Employers Could Face Harassment Claims Arising from Internet Use, 149 N.J. L.J., Sept. 1, 1997, at 33 (some paragraph breaks added); see also Eric Matusewitch, Workplace Cyberporn May Violate Discrimination Laws, 1997 ANDREWS EMPLOYMENT LITIG. REP. 21852 (Feb. 25, 1997), reprinted in Feb. 1997 ANDREWS SEXUAL HARASSMENT LITIG. REP. 3 (written by a Senior Equal Employment Opportunity Specialist for the New York Equal Employment Practices Commission):

Recent news accounts indicate that male employees are rummaging through cyberspace for sexually explicit images. The viewing of these X-rated webpages in the workplace could create an uncomfortable and humiliating atmosphere for female colleagues. 
This makes sense as a matter of substantive harassment law: For instance, if I (a Jew) know that my co-worker says virulently anti-Semitic things outside my presence, I might find it hard to work around him even if he's never rude to my face. Having to work around people who hate you, even politely hate you, might well create a "hostile, abusive, or offensive work environment." In the words of a California Court of Appeal case, "personal observation is not the only way that a person can perceive, and be affected by, harassing conduct in the workplace. One can also be affected by knowledge of that harassment." ${ }^{, 35}$ Thus, harassment law provides no safe harbor even when one is talking to co-workers who one knows won't be offended - any bigoted statements made at work may lead to harassment liability.

And employers seem to be getting the message-better to restrict any potentially actionable speech than to risk a lawsuit. Two Salomon Smith Barney executives were recently fired for accessing pornography and transmitting it between themselves. ${ }^{36}$ This likely wouldn't have happened but for Salomon's fear of legal liability, especially since executives' time is generally not closely monitored by management: In fact, one of the plaintiffs in an earlier sexual harassment lawsuit against Salomon has been quoted as saying, "They wouldn't have been fired four years ago, before our lawsuit .... [Before the lawsuit,] male co-workers used fax machines to send pornography and passed around explicit materials. Nothing was ever done about it." ${ }^{37}$ Likewise, the New York Times recently fired twenty staffers for sending "inappropriate and offensive" e-mail, "cit[ing] a need to protect itself against liability for sexual harassment claims.",38

Based on civil rights case law, companies need to recognize and address this emerging issue before it reaches the courts.

Pornographic Material in the Workplace

There is a growing legal recognition that pornographic and obscene material in the workplace can constitute sexual harassment and violate state and federal civil rights laws [citing an EEOC policy and court decisions]....

Visual Displays Alone Can be Harassment

.. Pornography, explained the court [in Robinson v. Jacksonville Shipyards], "creates a barrier to the progress of women in the workplace because it conveys the message that they do not belong, that they are welcome in the workplace only if they subvert their identities to the sexual stereotypes prevalent in that environment." ...

... The Robinson court, as part of the order and judgment, directed the employer to implement the Shipyard's Sexual Harassment Policy, which included a prohibition against "reading or otherwise publicizing in the work environment materials that are in any way sexually revealing, sexually suggestive, sexually demeaning or pornographic." [The implications for employers are that] [c]ompanies should consider updating their harassment policies to prohibit the viewing of sexually explicit sites in the workplace and explore the installation of software to block employee access to "adult" material.

35. Beyda v. City of Los Angeles, 76 Cal. Rptr. 2d 547, 552 (Ct. App. 1998).

36. See Peter Truell, 2 Executives Dismissed by Salomon Over Pornography, N.Y. TIMES, Mar. 31, 1998, at D9; see also Beth Piskora \& Kimberly Seals McDonald, The Check Is on the E-Mail at Salomon, N.Y. Post, Mar. 21, 1999, at 65 (discussing Salomon's continuing push to eliminate sexually themed e-mail).

37. James T. Madore, Smith Barney Suit Has Far-Reaching Effects, NEWSDAY, Apr. 5, 1998, at A5.

38. Michael Clark, 20 Office Workers in Norfolk Fired for Pornographic E-Mail Exchanges, NoRfolK Virginian-PILOT, Dec. 1, 1999, at A1; see also, e.g., 7 at 1st Union Fired for X-Rated EMail, AMERICAN BANKER, Sept. 1, 1999, at 5 (quoting company spokeswoman as saying that the com- 
The government, through threat of massive legal liability, is pressuring people to block access to material that it finds offensive. Obviously, private employers may, on their own, choose to restrict speech on their computers-just like private publishers may choose (and routinely do choose) not to publish profane, insulting, or politically offensive material, and just as Internet service providers may choose to restrict the material that they carry and to which they allow access. But when the law uses the threat of legal liability to pressure publishers or service providers into restricting speech on their property, the First Amendment is implicated. ${ }^{39}$ This is exactly what happens with harassment law.

True, the law isn't demanding a total ban: People whose Web access is blocked and whose e-mail is restricted because of the legal pressure can still read and write from home, though even from home they should not send e-mail to coworkers who might be offended, since a hostile environment at work may be created by speech sent from one employee's home e-mail address to another's. ${ }^{40}$ But the Communications Decency Act didn't impose a total ban, either-it would have still let people read and post what they wanted, so long as the material was difficult for minors to access, which probably meant that the sites would have had to charge for access using a credit card. ${ }^{41}$ The Supreme Court correctly concluded that this burden, even though it wasn't a total ban, violated the First Amendment; the same should go for the burden imposed on speech by harassment law.

What's more, harassment law is in many ways broader than the CDA; the CDA, at least, didn't purport to cover allegedly racist, sexist, or religiously insulting statements. The CDA would not have imposed liability for ebonics jokes (unless they contained highly explicit sexual or excretory references), or for most Clinton-Lewinsky jokes. And the one other body of law that refers to "indecent speech"- the regime governing television and radio broadcasting-tolerates such jokes, as long as they aren't extraordinarily graphic.

pany does not allow e-mail that "interferes with another person's work performance or creates an intimidating, offensive, or hostile environment," language clearly borrowed from the legal definition of workplace harassment); Janice C. Sipior \& Burke T. Ward, The Dark Side of Employee Email, COMMUNICATIONS OF THE ACM, July 1, 1999, at 88 ("To minimize potential [harassment] liability, employers are beginning to take action against employees whose email is deemed inappropriate. After sending coworkers several sexually explicit jokes, Michelle Murphy, a former customer service representative, was fired from [an insurance company]. The jokes included 'A Few Good Reasons Cookie Dough is Better Than Men' and 'Top 10 Reasons Why Trick-or-Treating Is Better Than Sex.'”).

39. See, e.g., New York Times, Inc. v. Sullivan, 376 U.S. 254 (1964).

40. See, e.g., Intlekofer v. Turnage, 973 F.2d 773, 775 (9th Cir. 1992) (relying in part on a co-worker "telephoning [Intlekofer] at her home" to support a hostile environment claim); Bersie v. Zycad Corp., 399 N.W.2d 141, 143, 146 (Minn. Ct. App. 1987) (relying in part on a co-worker "calling [Bersie] at home" to conclude that plaintiff had made a prima facie showing of harassment); $c f$. Bartlett v. United States, 835 F. Supp. 1246, 1262 (E.D. Wash. 1993) (finding that two instances of sexually suggestive conduct, including "[p]laintiff receiv[ing] a sexually explicit card at her home from a co-worker," did not rise to the level of sexual harassment, but not even hinting that the card was somehow categorically disqualified because it was received outside the workplace); Myer-Dupuis v. Thomson Newspapers, No. 2:95-CV-133 (W.D. Mich. May 9, 1996), reported in MICH. LAW. WKLY., May 27, 1996, at 12A. These cases are eminently consistent with the standard definition of harassment: It's quite plausible that speech by co-workers outside the workplace may create a hostile environment within the workplace.

41. See Volokh, supra note 15 , at 143 . 
But harassment law is not limited to indecency; it operates to generally suppress speech, whether or not sexually explicit or highly profane, that is potentially offensive based on race, religion, sex, and so on. ${ }^{42}$ And the evidence of harassment law's chilling effect on protected speech ${ }^{43}$ is much more concrete than the speculative (though plausible) evidence on which the Court relied in Reno v. ACLU. ${ }^{44}$ Harassment law goes where the CDA was forbidden to tread-and so far it hasn't been stopped.

I have detailed elsewhere why such application of harassment law is unconstitutional. ${ }^{45}$ Here, I want to make three observations, foreshadowed in the Introduction, about cyberspace speech, harassment law, and the Clinton Administration.

First, the constitutional status of harassment law's suppressing cyberspace speech in and from private workplaces has little to do with any special attributes of cyberspace, but much to do with broader medium-independent free speech issues. True, the cyberspace examples may show harassment law's constitutional problems especially starkly, because the availability of filters makes it particularly easy for prudent employers to be pushed by the law into restricting speech. True, cyberspace speech is somewhat unusual in that many employers provide free cyberspace access, and therefore many people use cyberspace overwhelmingly from the workplace. But generally the issues are the same as they would be outside cyberspace; as another article, entitled Workplaces Wage War on Internet Porn, says (quoting Elizabeth du Fresne, an employment lawyer):

We all know you can't hang up a Penthouse calendar in the workplace. We know you can't make a racist joke. It would be the same if you got either from the Internet .... The source is not the issue. It's that during the day, you got it and brought it into the workplace.

42. On the other hand, sexually indecent speech will in general be potentially punishable by harassment law (though excretorily indecent speech might not be).

43. See Volokh, supra note 10.

44. 521 U.S. at 871-72.

45. See Freedom of Speech v. Workplace Harassment-A Growing Conflict $<$ http://www.law.ucla. edu/faculty/volokh/harass $>$, which contains updated versions of Eugene Volokh, Freedom of Speech and Workplace Harassment Law, 39 UCLA L. REV. 1791 (1992), Volokh, supra note 10, and some other pieces.

46. Susana Barciela, Workplaces Wage War on Internet Porn, MiAmi Herald, Aug. 4, 1996, at 1F (quoting Elizabeth du Fresne, an employment lawyer); see also Mark Grossman \& Sarah Santoro, Employee E-Mail Presents Problems, LEGAL TIMES, June 14, 1999, at 21 ("[E]mployees who visit adult sites while at the office could be creating a 'hostile work environment' under sexual harassment law.... [P]rohibiting access to adult material on the Internet is an essential part of your [acceptable use policy].... Your [policy] should restrict the use of any type of offensive, harassing, fraudulent, defamatory or otherwise illegal language in e-mail."); Denise Grady, Keeping Track of Employees' On-Line Voyeurism, N.Y. TIMES, May 7, 1998, at G3 (advising the use of filters because "people who dally with Net pornography at work may leave a corporation open to sexual-harassment lawsuits by co-workers offended by the lewd images"); David Plotnikoff, Online Oversight, SACRAMENTO BEE, Nov. 22, 1998, at G1 ("The possibility of lengthy and expensive lawsuits stemming from claims of sexual harassment, discrimination and hostile-workplace environments has many firms rushing to put ironclad restrictions in place before a problem comes to light."); Katy Robinson, On-the-Job Surfers Cost Firms Big Bucks, IDAHO STATESMAN, Feb. 23, 1998, at 1D (advising use of filters because "[t]here is increased corporate exposure to potential liability in harassment cases); Wayne Tompkins, More Companies Let Their Workers Surf Web at Work, COURIERJOURNAL (LOUISVILLE), June 13, 1999, at 1E ("An employee surfing an adult side ... opens the door to 
The medium "is not the issue"- the issue is whether, in a nation that's supposedly protected by the First Amendment, racist jokes or Penthouse calendars may be made legally punishable.

Second, this section began with a case brought by the Clinton Administration's EEOC, but the EEOC isn't really taking the lead in this area. Many of the other cases cited above were filed by private plaintiffs and litigated under doctrines that were mostly developed by courts with fairly little help from the EEOC. Still other important cases in which harassment law has restricted free speech have been litigated under state harassment laws. ${ }^{47}$

Here, as elsewhere, the Clinton Administration has had no campaign focused on remolding First Amendment law or suppressing some sort of speech. Rather, various government players and private litigants are trying to accomplish other policy goals-for instance, improving the culture of American business in a way that they hope will lead to a more just society, or simply winning a harassment claim against an ex-employer-and free speech defenses are only an incidental barrier to be overcome. If the Clinton Administration does substantially damage free speech through harassment law-or does substantially protect free speech against harassment law-this will happen through its judicial appointments, not its executive or legislative agenda. ${ }^{48}$

Third, it is doubtful that in 1980, when hostile environment harassment law was still in its infancy and was rarely applied to otherwise protected speech, the federal government would have claimed that the law requires that certain jokes be "eradicate[d]." Likewise, if the Internet had arisen in 1980, there would have at that time been little legal pressure to filter Web access and e-mail. Perhaps a highly ideological Administration might have tried to assert such claims, but I doubt that a 1980 version of the Clinton Administration would have.

But as radical proposals are accepted and become part of the status quo, the unthinkable or unlikely becomes eminently plausible. Harassment law started by going after face-to-face racial slurs; few people wanted to defend those on

sexual-harassment suits."). Companies already have encountered cases in which employees sue them, saying they are offended by material their co-workers have downloaded from the Internet."); Lou Gonzales, XXX Mail; Employers Worry About Pornographic "Spam" in the Office, COlORADO SPRINGS GAZETTETElEgraPH, Jan. 30, 1998, Business sec., at 1; Blaise Zerega, SurfWatch Cleans Up Net Use, INFOWorLD, April 13, 1998, at 62.

47. See, e.g., Brown Transp. Corp. v. Commonwealth, 578 A.2d 555, 562 (Pa. Commw. Ct. 1990); Dernovich v. City of Great Falls, Mont. Hum. Rts. Comm'n No. 9401006004 (Nov. 28, 1995) (on file with author).

48. So far, very few court decisions have confronted the tension between the freedom of speech and workplace harassment law; I list virtually all such cases at <http://www.law.ucla.edu/faculty/volokh/ harass/courts.htm>. About a dozen opinions have expressed some sympathy for the free speech defense, at least in some situations; a few have actually accepted it, in limited contexts; another half dozen or so opinions have rejected it in particular contexts, while leaving open the possibility that it may be valid in other cases; and several have generally rejected it out of hand. The great majority of the cases are from trial courts. 
First Amendment grounds, ${ }^{49}$ though such a defense is not frivolous. ${ }^{50}$ Then it went after workplaces plastered with massive amounts of pornography. Then it went after sexist speech about women not belonging in the workplace. ${ }^{51}$ Then it went after religious proselytizing and sexually themed jokes. ${ }^{52}$

This tendency was exacerbated by the fact that harassment law is enforced by dozens of government agencies and thousands of litigants all over the country. Even if some hesitate to bring claims based on speech that has not historically been seen as "harassing," others won't. And once these plaintiffs win, they set a precedent that others may use, and their victory redefines formerly unactionable speech as potential fodder for a harassment lawsuit.

Given all that, even a relatively middle-of-the-road Administration can now find it easy to sue over ebonics jokes, and many employers rightly fear that politically offensive e-mail or pornographic images glimpsed on co-workers' computers will lead to liability. Narrow speech restrictions do over time lead to broader ones.

III

\section{THE HidDen CAMPUS SPEECH CODE}

In late 1994, the Santa Rosa Junior College newspaper ran an advertisement containing a picture of the rear end of a woman in a bikini. A student, Lois Arata, thought the advertisement was sexist; when the newspaper refused to let her discuss this concern at a staff meeting, she organized a boycott of the newspaper and wrote to the College Trustees to express her objections.

This led to a hot debate in a chat room on SOLO, a college-run online bulletin board for students, and some of the debate contained personal attacks on Arata and on Jennifer Branham, a female newspaper staffer. Some of the messages referred to Arata and Branham using "anatomically explicit and sexually deroga-

49. Even I think such one-to-one statements should generally be constitutionally unprotected, even when they fall outside the fighting words exception. See Volokh, supra note 45, at 1863-67; <http:// www.law.ucla.edu/faculty/volokh/harass/permissi.htm $>$.

50. See, e.g., Gooding v. Wilson, 405 U.S. 518, 528 (1972) (concluding that speech can be punished as "fighting words" only when there is a "likelihood that the person addressed would make an immediate violent response").

51. See, e.g., Bowersox v. P.H. Glatfelter Co., 677 F. Supp. 307, 308 (M.D. Pa. 1988); Arnold v. City of Seminole, 614 F. Supp. 853, 863 (E.D. Okla. 1985).

52. See Brown Transp. Corp. v. Commonwealth, 578 A.2d 555, 562 (Pa. Commw. Ct. 1990) (religious proselytizing); Hilsman v. Runyon, 1995 WL 217486, at*3 (E.E.O.C. Mar. 31); Peck v. Sony Music Corp., 68 Fair Empl. Prac. Cas. (BNA) 1025, 1995 WL 505653, at *2 (S.D.N.Y. Aug. 25); Cardin v. Via Tropical Fruits, Inc., No. 88-14201 (sexually themed jokes), corrected on other matters by 7 FLA. L. WEEKLY FED. D. 730, 1993 U.S. Dist. LEXIS 16302, at *24-25 \& n.4 n. 61 (S.D. Fla. July 9); Dernovich v. City of Great Falls, Mont. Hum. Rts. Comm'n No. 9401006004 (Nov. 28, 1995) (same); Garber v. City of Minneapolis, No. MDCR-91262-EM-7, at 1, 4, 19 (Minneapolis Comm'n on Civ. Rts. July 31, 1996) (same); Marr v. Widnall, 1996 WL 375789, *8 (E.E.O.C. June 27) (same). I have also found a fairly early religious proselytizing case, In re Sapp's Realty, Inc., Or. Comm'r of Bureau of Labor \& Indus., Case No. 11-83, at 47-48, 66-68 (Or. Bureau Labor \& Indus. Jan. 31, 1985). 
tory" terms..$^{53}$ Arata and Branham quickly learned of the messages (the two weren't chat room members themselves) and complained to the college, which put the journalism professor who had set up the bulletin board on administrative leave pending an investigation.

This suspension naturally intensified the controversy. Some of the new SOLO posts insulted Arata's personal appearance and said that she was protesting the ad because she was jealous. Others called Arata a "fascist" and a "feminazi fundamentalist." ${ }^{54}$ Branham, the newspaper staffer, was especially criticized. At two newspaper staff meetings, many of her fellow staffers "directed angry remarks at [her] and blamed her for the journalism professor's absence." Another staff member produced a parody "lampoon[ing] the newspaper's coverage of Branham's complaint, implying that the complaint was trivial.",55

I have no doubt that Arata and Branham were genuinely upset by this speech; but, especially on a college campus, such speech, warts and all, seems to be the sort of "uninhibited, robust, and wide-open" debate ${ }^{56}$ that we must expect when people debate issues that are important to them. Likewise, I had thought people were free to criticize classmates who organize boycotts or file complaints against a newspaper, bulletin board, or a respected community figure, even if the criticisms are unfair, personal, and intemperate..$^{57}$

The U.S. Department of Education Office for Civil Rights, however, took a different view. The students' speech, the OCR concluded, created a "hostile educational environment" for Branham based on her sex, and for Branham and Arata based on their actions in complaining about the original posts. ${ }^{58}$ What about the First Amendment? Well, the OCR reasoned,

[s]tatutes prohibiting sexual harassment have been upheld against First Amendment challenges because speech in such cases has been considered indistinguishable from other illegal speech such as threats of violence or blackmail... . The Supreme Court has repeatedly asserted that the First Amendment does not protect expression that is

53. Letter from John E. Palomino, Regional Civil Rights Director of the United States Department of Education Office for Civil Rights, to Dr. Robert F. Agrella, President of Santa Rosa Junior College, in case no. 09-93-2202, at 2 (June 23, 1994).

54. Id. at 12.

55. Id. at 13-14.

56. New York Times, Inc. v. Sullivan, 376 U.S. 254, 270 (1964); see also UWM Post, Inc. v. Board of Regents, 774 F. Supp. 1163, 1179 (E.D. Wis. 1991) (specifically mentioning this in the context of a university ban on speech that creates a "hostile educational environment").

57. See, e.g., Hustler Magazine v. Falwell, 485 U.S. 46 (1988).

58. Letter, supra note 53 , at $7,13,15$. The OCR concluded that the seven original posts criticizing Arata weren't enough to create a hostile environment for her, but the four original posts about Branham were enough, apparently because they were written by Branham's fellow staffers, whom "she had considered ... to be her friends prior to her discovery of the message," and because as a result of the posts "she was unable to work effectively on the newspaper staff after that time." The OCR concluded that the posts that followed Arata's and Branham's original harassment complaints were enough to create a hostile environment both for Arata and Branham. The message was posted in a men-only chat room-because women students had requested women-only chat rooms, SOLO included men-only and women-only chat rooms as well as integrated ones, see MIKE GODWIN, CYBER RIGHTS: DEFENDING FREE SPEECH IN THE DigitAl AGE 103 (1998) - but this factor didn't affect the OCR's harassment analysis. 
invidious private discrimination. Thus, the First Amendment is not a bar to determining whether the messages . . created a sexually hostile educational environment. ${ }^{59}$

Moreover, the OCR had a plan to prevent such "illegal speech" in the future. "A new paragraph," the plan said, "shall be added to the [Santa Rosa Junior College] "Administrative Computing Procedures," which shall bar (among other things) online speech that "harass[es], denigrates or shows hostility or aversion toward an individual or group based on that person's gender, race, color, national origin or disability, and ... has the purpose or effect of creating a hostile, intimidating or offensive educational environment." And this prohibition shall cover "epithets, slurs, negative stereotyping, or threatening, intimidating or hostile acts ... that relate to race, color, national origin, gender, or disability," including "acts that purport to be 'jokes' or 'pranks,' but that are hostile or demeaning." This is of course at least as broad as many of the campus speech codes that were struck down in the late 1980s and early $1990 \mathrm{~s}^{60}$ —again, harassment law goes where the government has before been told it may not tread. Rather cryptically, the proposed speech code ends with "Nothing contained herein shall be construed as violating any person's rights of expression set forth in the Equal Access Act or the First Amendment of the United States Constitution."

The College settled the case by paying the complainants $\$ 15,000$ each, and by adopting the OCR's policy. ${ }^{62}$ At a college run by the state government, and under pressure from the federal government, cyberspace communications containing "negative stereotyping," "denigrat[ion]," and "hostility or aversion" based on race or sex are now "illegal speech." And other administrators and legal experts agree; in the words of a New Jersey Law Journal article co-written by a computer science professor and a state court judge,

[a]lthough a school [in context, referring to colleges and universities] by its very nature must provide for the guarantees of free speech as to classroom expression and assignment, the use of computers, [and] access to the Internet in open computer labs, should be appropriately regulated to avoid a hostile environment for offended students. Not to take such preventive actions at the ... school is to place the ... school at risk. ${ }^{63}$

59. Letter, supra note 53, at 7.

60. See Dambrot v. Central Mich. Univ., 55 F.3d 1177 (6th Cir. 1995); Iota Xi v. George Mason Univ., 993 F.2d 386 (4th Cir. 1993); UWM Post, Inc v. Board of Regents, 774 F. Supp. 1163 (E.D. Wis. 1991); Doe v. University of Mich., 721 F.2d 852 (E.D. Mich. 1989).

61. Letter, supra note 53, attachment 3 (Proposed Remedial Action Plan).

62. See <http://www.santarosa.edu/polman/2govern/2.13.p.htm> (visited Mar. 27, 2000); <http:// grimmy.santarosa.edu/nermal/pol.html> (visited Mar. 27, 2000); Agreement between Arata, Branham, and Humphrey and the Sonoma County Junior College District, Sept. 14, 1994; see also, e.g., North Georgia Tech, Computers: Acceptable Use Policy <http://www.clarkes.tec.ga.us/general/accepuse.html> (visited Mar. 20, 2000) (imposing a similar online speech code); Policy and Procedures for Computer and Electronic Communication Access and Usage at Anne Arundel Community College §§ II, III.B $<\mathrm{http}: / /$ www.aacc.cc.md.us/ computerusage.htm> ("Students, faculty, staff and authorized guest users have a right to be free from electronic harassment by any member of the college community on the basis of their sex, sexual orientation, race, national origin, age, religion, handicap or veteran status. Creating a sexually and/or racially intimidating, hostile or offensive environment is prohibited by college policy. ... [I] nappropriate use includes ... [h] arassment of any type or form.").

63. Powals \& Powals, supra note 34, at 33. 
I think that such restrictions are unconstitutional, but again the details of this argument (and of the counterarguments) have been amply discussed elsewhere. Here I only want to suggest that this incident, like the incidents discussed in Part I, lends support to my three basic points.

First, the free speech issue here has little to do with the speech being in cyberspace. The Santa Rosa incidents started with online posts, but then went on to include a printed parody and oral comments at a newspaper staff meeting; the OCR correctly treated them similarly, because there was no real reason to treat them differently. And the hostile educational environment theory is already being used elsewhere to justify general speech codes that likewise apply equally to cyberspace speech and to other speech: Consider, for instance, a 1996 Kansas Attorney General Opinion, which argues that campus speech codes are constitutionally permissible, so long as they are written by analogy to hostile work environment law ${ }^{64}$ or the Central Michigan University speech code, which prohibited any behavior creating a "hostile or offensive" educational environment and was struck down in Dambrot v. Central Michigan University. ${ }^{65}$

Second, the Clinton Administration is again mostly just tagging along for the ride. True, the Department of Education is pushing for speech restrictions. Besides the SOLO case, consider the Department of Education's Sexual Harassment in Higher Education-From Conflict to Community, which lists "sexist statements and behavior that convey insulting, degrading, or sexist attitudes" as examples of "sexually harassing behavior." Likewise, consider the OCR publication Sexual Harassment: It's Not Academic, which states that even in universities, "displaying or distributing sexually explicit drawings, pictures and written materials" may constitute harassment if it is unwelcome and "severe, persistent, or pervasive" enough. ${ }^{67}$

Still, the OCR is only doing what the Kansas Attorney General, Central Michigan University, and others are doing. Maybe a more ideological Administration might have tried to lead some sort of anti-"hate-speech" crusade, but that's not what happened under Clinton. Rather, we have a specialist agency quietly trying to implement its own goal (protecting people against racist or sexist behavior) and seeing the First Amendment as largely an incidental barrier to be overcome if it's easy to do so.

64. Kan. Att'y Gen. Op. 96-1, 1996 WL 46866; see also Rutgers, The University's Policy Prohibiting Harassment <http://www-rci.rutgers.edu/ msgriff/webdoc5.htm> (effective Sept. 1, 1997) (transplanting workplace harassment definition into educational context, and giving "[d]isplay of offensive material or objects" and "[i]n some instances, innuendo or other suggestive, offensive or derogatory comments or jokes about sex, gender-specific traits" or "race, religion, color, national origin, ancestry, age, sex, sexual orientation, disability, marital or veteran status" as examples of potentially prohibited speech).

65. 55 F.3d 1177 (6th Cir. 1995); see also UWM Post, Inc. v. Board of Regents, 774 F. Supp. 1163 (E.D. Wis. 1991).

66. U.S. Dep't of Educ., Sexual Harassment in Higher Education-From Conflict to Community (1993) <http://www.ed.gov/databases/ERIC_Digests/ed364134.html> (visited Mar. 27, 2000).

67. U.S. Dep't of Educ. Office for Civil Rights, Sexual Harassment: It's Not Academic (1997) $<$ http://www.ed.gov/offices/OCR/ocrshpam.html> (visited Mar. 27, 2000). 
Third, we see here how narrow speech restrictions beget broader ones. The OCR's argument starts with the uncontroversial assertion that threats and blackmail are punishable as "illegal speech." Then comes the assertion, which the OCR treats as uncontroversial, that harassing speech in workplaces (the subject of the statutes to which the OCR must have been referring) is likewise illegal speech. Then it follows that such speech in colleges is illegal speech.

Similarly, consider the OCR's argument that "The Supreme Court has repeatedly asserted that the First Amendment does not protect expression that is invidious private discrimination." ${ }^{68}$ It's true that the Court held that the First Amendment does not protect discriminatory acts, such as refusals to admit people into a school, university, or club, refusals to promote people, or the selection of a victim for a physical assault. ${ }^{69}$ It's also true that in R.A.V. v. City of St. Paul, the Court said in dictum that a "content-based subcategory of a proscribable class of speech" such as "sexually derogatory 'fighting words,' among other words" might be punishable by harassment law, without discussing whether harassment law may constitutionally punish otherwise nonproscribable, constitutionally protected speech. $^{70}$ But from here the OCR makes an analogical jump, inferring from cases discussing bans on conduct and on constitutionally unprotected speech (such as fighting words) that the government may punish as "illegal speech" any expression that may create a "hostile, abusive, or offensive" environment and that thus supposedly constitutes "invidious private discrimination."

Analogy is a powerful force in our legal system. Supporters of workplace harassment law regularly use existing restrictions-such as obscenity law and bans on fighting words-as justification. ${ }^{71}$ It's hardly surprising that workplace harassment law would then itself be used as an analogy to justify educational harassment law.

68. Letter, supra note 53, at 7.

69. Norwood v. Harrison, 413 U.S. 455, 469 (1973) (rejecting supposed freedom of association right to discriminate in school admissions, though stressing that the school had a First Amendment right to teach racist doctrines); Runyon v. McCrary, 427 U.S. 160, 175 (1976) (same); Hishon v. King \& Spalding, 467 U.S. 69, 78 (1984) (rejecting supposed freedom of association right to discriminate in promoting employee to partnership); Roberts v. United States Jaycees, 468 U.S. 609 (1984) (rejecting supposed freedom of association right to discriminate in selecting members of a large private club); Bob Jones Univ. v. United States, 461 U.S. 574 (1983) (rejecting supposed Free Exercise Clause right to discriminate based on race in college admissions and college policies); Wisconsin v. Mitchell, 508 U.S. 476 (1993) (rejecting supposed First Amendment right to be free from extra punishment for discriminatory selection of a victim for one's crimes).

70. 505 U.S. 377, 389 (1992) (emphasis added). The Court made clear that "proscribable" refers to the traditional First Amendment exceptions, such as obscenity, fighting words, and defamation. I discuss $R . A . V$. and its impact on the constitutional questions surrounding harassment law at $<\mathrm{http} / / \mathrm{www}$. law.ucla.edu/faculty/volokh/harass/substanc.htm\#RAV> (visited Mar. 27, 2000), which elaborates on my earlier argument in Workplace Harassment, supra note 45, at 1829-32.

71. See, e.g., David B. Oppenheimer, Workplace Harassment and the First Amendment: A Reply to Professor Volokh, 17 BERKELEY J. EMP. \& LAB. L. 321, 322-25 (1996). 
IV

\section{HOSTILE PUBlic ACCOMMODATIONS ENVIRONMENT LAW}

Katherine Kavanagh used Goddard College as her Internet service provider; she had been a graduate student and a lecturer there, but no longer was-her relationship to the College was the same as yours might be to America Online.

The site http://www.kinkycards.com, which describes itself as "Electronic Greeting Cards Tastefully Designed for Friends and Lovers," can be used to email someone a sexually themed electronic greeting card. The site prompts for your choice of card, a text message to go with the card, your e-mail address, and the recipient's e-mail address; it then sends the recipient an e-mail pointing to the selected greeting card, and sends you a confirmation e-mail. In June 1998, Alex Johnson-a Goddard employee who knew Kavanagh — apparently went to kinkycards.com and, pretending to be Kavanagh, sent two greeting cards to himself. Kavanagh got the confirmation e-mails, checked out the cards, became upset, and filed a complaint with the Vermont Human Rights Commission.

The Commission concluded that because these two e-mails "came into Ms. Kavanagh's home and as a result [were] particularly threatening" and led her to close her e-mail account, they "created a hostile [public accommodations] environment." ${ }^{12}$ And the Commission's syllogisms on this score were, as a matter of statutory interpretation, impeccable:

(1) Hostile environment harassment is a form of discrimination-the very theory under which harassing speech was first found to be punishable in employment.

(2) Vermont law bans sex discrimination in places of public accommodations. ${ }^{73}$

(3) Therefore, speech that creates a hostile environment in places of public accommodation and on Internet services is also discrimination, and also illegal. ${ }^{74}$

(4) Internet access services are places of public accommodation no less than, say, restaurants, theaters, and libraries, which are quintessential examples of places of public accommodation. ${ }^{75}$ (Certainly if America Online, for instance, refused to sell accounts to blacks or

72. Investigative Report, Kavanagh v. Goddard College, charge no. PA99-0002, at 16 (Vt. Hum. Rts. Comm'n Mar. 10, 1999).

73. Id. at 4-5.

74. See also Brown v. St. Johnsbury Supervisory Union, No. PA98-0035 (Vt. Hum. Rts. Comm'n Sept. 9, 1998) (taking the view that Vermont law bars hostile public accommodations environment harassment based on perceived sexual orientation); Fulton v. Bellows Free Academy, No. PA98-0027 (Vt. Hum. Rts. Comm'n Aug. 12, 1998) (same as to race); Rodger v. Steve's Market, Inc., No. PA98-0057 (Vt. Hum. Rts. Comm'n Apr. 14, 1999) (same as to disability).

75. See Eugene Volokh, Freedom of Speech in Cyberspace from the Listener's Perspective, $1996 \mathrm{U}$. CHI. Legal F. 377, 390-97 (discussing this in more detail); Stuart Biegel, Hostile Connections, L.A. DAILY J., Aug. 22, 1996, at 7 (endorsing such an approach, and suggesting that service providers may have a duty to restrict certain speech under hostile public accommodations environment law). 
Jews or women, many people would argue that this discrimination is just as actionable as a restaurant refusing to sell food to these groups.)

(5) Goddard College is thus the proprietor of a place of public accommodation-an Internet access service. As such, it has a legal obligation to "take immediate and appropriate steps ... reasonably calculated to end any harassment, eliminate a hostile environment if one has been created, and prevent harassment from occurring again" " which is to say prevent offensive speech that's severe or pervasive enough to create a hostile, abusive, or offensive environment based on race, religion, sex, and so on.

The Commission didn't discuss the First Amendment implications of all this, apparently because the constitutional defense was not raised by Goddard College. After the Commission's decision, the College settled the case on undisclosed terms. ${ }^{77}$

The speech involved in this case-a prank played on an acquaintance-may not seem that important, but the implications of importing hostile environment law into the public accommodations context are dramatic. We know hostile environment law goes far beyond pranks: If the Vermont Human Rights Commission is right, then posts to America Online discussion groups containing, say, ebonics jokes, sexist criticisms of a perceived troublemaker, or ClintonLewinsky jokes can also be illegal hostile public accommodations environment harassment. America Online will have a legal duty to delete these posts as soon as it gets a complaint, and perhaps even filter them out if it can (for instance, in discussion groups moderated by its employees or contractors).

Nor is the Vermont Human Rights Commission alone in accepting a hostile public accommodations environment theory:

- Several state statutes explicitly prohibit "communication of a sexual nature" that creates "an intimidating, hostile, or offensive ... public accommodations environment."

76. Investigative Report, Kavanagh v. Goddard College, charge no. PA99-0002, at 14-16 (Mar. 10, 1999); see also Final Determination, Kavanagh (concluding there was probable cause to hold Goddard liable).

77. E-mail from UCLA School of Law librarian Kevin Gerson to me based on his conversation with the college's lawyer, Mar. 16, 2000.

78. Mich. COMP. LAws ANN. § 37.2103(i) (2000); see also Minn. StAT. ANN. § 363.01, subd. 41 (2000); MONT. ADMIN. R. 24.9.609(2)(c) (1999) (covering harassing speech based on race, religion, and other attributes, as well as sex); N.D. CENT. CODE § 14-02.4-01 to -02 (2000) (prohibiting discrimination in public accommodations and defining discrimination to include sexually harassing speech); COOK COUnTY, Ill. ord. no. 93-0-13 art. V(c); EAst LANSING, Mi. City CODE $\S \S 1.120(1), 1.22(4)$, $1.27(3)$ (b) (covering harassing speech based on race, religion, and other attributes, as well as sex); CAMBRIDGE, MASS. HUMAN RIGHTS ORDINANCE $\$ 2.76 .120$ (N) ("It is an unlawful practice for any person to harass ... any person in or upon any public accommodation because of the race, color, sex, age, religious creed, disability, national origin or ancestry, sexual orientation, gender, marital status, family status, military status or source of income of such person, or attempt to do so."); $c f$. Pennsylvania Human Rels. Comm'n publication (no date) (saying that Pennsylvania state discrimination law bans public accommodations harassment "on the basis of your race, color, religion, national origin, ancestry, 
- Other statutes that speak only of discrimination have also been interpreted as barring harassment; for instance, a Wisconsin administrative agency has concluded that an overheard (though loud) discussion that used the word "nigger" created an illegal hostile public accommodations environment for black patrons, even though the statements weren't said to or about the patrons. ${ }^{79}$

- The Minnesota Supreme Court has held a health club liable for creating a hostile public accommodations environment, based on the club owners' "belittl[ing]" a patron's religious views (expressed in a book the patron had written) and "lectur[ing] her on fundamentalist Christian doctrine." ${ }^{\text {" }}$

age (40 and above), sex, disability, use of a guide animal or having a GED instead of a high school diploma"); Iowa Civil Rights Comm'n, Sexual Harassment in the Workplace: It's Against the Law $<$ http://www.state.ia.us/government/crc/factsheetlist.html> (visited Mar. 28, 2000) ("The Laws That Prohibit Harassment ... . The 'Iowa Civil Rights Act of 1965' . . . does not expressly define or prohibit sexual harassment, but such behavior is recognized by the courts as a form of prohibited sex discrimination. The state law ... prohibit[s] sex discrimination in the areas of housing, public accommodations, credit and education."); New Jersey Dep't of Law \& Pub. Safety, Sex Discrimination: Your Rights ("Where is Sex Discrimination [earlier defined to include hostile environment harassment] Against the Law? .. Places of Public Accommodation"); New York City Comm'n on Human Rights, Mission Statement <http://www.ci.nyc.ny.us/html/cchr/html/mission/html > (visited Mar. 28, 2000) (saying that New York City human rights law bars in public accommodations harassment "on the basis of race, color, creed, age, national origin, alienage or citizenship status, gender, sexual orientation, disability, marital status ... lawful occupation ... and record of conviction or arrest").

79. Bond v. Michael's Family Restaurant, Wisc. Labor \& Indus. Rev. Comm'n, Case Nos. 9150755, 9151204 (Mar. 30, 1994). The case suggested that this theory may be limited only to speech by the restaurant owner, but a later case by the same agency made clear that the proprietor can be held liable for a hostile environment created by its patrons, so long as it is able to eject the patrons but declines to do so. Neldaughter v. Dickeyville Athletic Club, Wisc. Labor \& Indus. Rev. Comm'n, Case No. 9132522 (May 24, 1994); see also D'Amico v. Commodities Exchange, Inc., 1997 N.Y. App. Div. LEXIS 506 (holding that proprietor of a place of public accommodations was responsible for harassment of a patron by fellow patrons).

See also Harris v. American Airlines, Inc., 55 F.3d 1472 (9th Cir. 1995) (passenger sued airline based on racist statement made by a fellow passenger; court held that in the airline context such state claims are preempted by federal aviation law), overruled by Charles v. TransWorld Airlines, 160 F.3d 1259 (9th Cir. 1998) (en banc) (holding that federal law does not preempt such claims); Hodges v. Washington Tennis Service Int'l, Inc., 870 F. Supp. 386 (D.D.C. 1994) (health club member sued club over racist statements made by employee; claim dismissed because heath club took remedial action); In re Totem Taxi, Inc. v. New York State Human Rights Appeal Bd., 480 N.E.2d 1075 (N.Y. 1985) (passengers sued taxi company over racist statements and threats made by taxi driver; claim dismissed because company had taken reasonable steps to prevent such conduct); Comm'n on Human Rights \& Opportunities v. Mills, case no. 9510408 (Aug. 5, 1998), CONN. LAW TRIB., Sept. 21, 1998 (recognizing hostile public accommodations environment cause of action); $c f$. King v. Greyhound Lines, Inc., 656 P.2d 349, 351 n.6 (Or. App. 1982) (customer sued bus company over racist statements made by an employee; court held for customer, but suggested that the law might not cover racist statements made by a fellow patron, and that employment harassment law might not be an apt analogy).

80. In re Minnesota by McClure v Sports \& Health Club, Inc., 370 N.W.2d 844, 853 \& n.16 (Minn. 1985); id. at 867 n.25, 872-73 n.40 (Peterson, J., dissenting); see also Department of Fair Emp. \& Housing v. University of Cal., 1993 WL 726830, *14 (Cal. F.E.H.C. Nov. 18) (interpreting California public accommodations law as applying to sexual and racial harassment). But see Haney v University of Ill., No. 1993SP0431, 1994 WL 880339 (Ill. Hum. Rts. Comm'n Sept. 1) (holding that state public accommodations law does not bar the creation of a hostile environment, in large part because of free speech concerns). 
- The Massachusetts Commission Against Discrimination has filed a complaint claiming that it's illegal for bars to put up racially offensive displays. The case involved a seasonal display containing some stuffed monkeys, a large stuffed gorilla wearing a crown, a wooden figure holding a spear, and coconuts painted with black faces and large red lips; a bartender allegedly told some patrons that the display was meant to "mock[] the celebration of Black History Month," and "the crowned gorilla was intended as a derogatory reference to Martin Luther King, Jr." The bar owner settled the case by agreeing to issue an apology, to contribute money to cosponsor events "addressing the topic of the history and contributions of Irish Americans and African Americans," and to fire the bartender (whose statements the bar owner had earlier disavowed). ${ }^{81}$

- The New Hampshire Human Relations Commission held an Elks Lodge liable for hostile public accommodations environment harassment on the grounds that its members made offensive statements to women who wanted to join the lodge. The Commission also held that the Lodge discriminated against the women when it failed to accept them as members, but it independently held the Lodge liable for its members' "derogatory and anti-female comments to them and about them to other members," and for the lodge's secretary writing in the Elks' newsletter "that the 'women's actions might destroy the lodge." The Elks had to pay a total of $\$ 64,000$ in damages and fines, based largely on the offensive speech. ${ }^{82}$

- An official publication of the South Dakota agency in charge of state antidiscrimination law says that "racist or sexist statements displayed in a public accommodation which affect a person's ability to use and enjoy those accommodations" are illegal. ${ }^{83}$

- Maine Human Rights Commission regulations specifically state that "unwelcome comments, jokes, ... and other verbal ... conduct related to [physical or mental] handicap" that creates an "intimidating, hostile,

81. Complaint, Mass. Comm'n Against Disc. v. Tom English's Cottage, Inc., MCAD Docket No. 00140427 (Feb. 26, 2000) (stating that such speech violated state public accommodations law); Terms and Conditions of Tom English Cottage Settlement, fax from MCAD to UCLA Law Library, Apr. 26, 2000.

82. Decision, Marcoux v. Franklin Lodge of Elks \#1280, PAS 6079-97, June 21, 1999, available at $<$ http://www.state.nh.us/hrc/Franklin.html>, appealed to N.H. Sup. Ct., case no. 99-813, available at $<\mathrm{http}: / /$ www.state.nh.us/courts/supreme/opinions/0003/caseacc.htm>; see also Hearing Examiner's Report and Recommendation, Flaa v. Manor Country Club, case no. PA-709 (Montgomery Cty. Hum. Rel. Comm'n Sept. 30, 1999) (concluding that sexually offensive remarks by club members constituted hostile public accommodations environment), rev'd, Memorandum Opinion and Order, Flaa v. Manor Country Club, OZAH Referral No. 98-28 (Montgomery Cty. Hum. Rel. Comm'n May 11, 2000) (holding that the public accommodations law did not cover hostile public accommodations harassment), appealed to $\mathrm{Md}$. Cir. Ct. date).

83. South Dakota Dep't of Commerce \& Reg. Div'n of Human Rights, Sexual Harassment (no 
or offensive environment on [a] public conveyance" (a commercial bus, boat, airplane, and the like) may be actionable hostile public accommodations harassment. The owner of the conveyance may be held legally liable for allowing such speech by its patrons so long as it "knows or should have known" of the speech and fails to take "immediate and appropriate corrective action."

- A Rhode Island state administrative agency found that the name "Sambo's Restaurants" was offensive to blacks and therefore violated public accommodations laws.

- In one Chicago Commission on Human Relations case, a customer had told a group of waitresses that "if it were his restaurant, he would probably fire all of them"; when he turned around and walked away, a waitress said "I don't know who he thinks he is, that holier than thou damn faggot." The Commission concluded this speech constituted hostile public accommodations environment harassment based on sexual orientation. ${ }^{86}$

- In another Chicago case, the Commission found that speaking to a customer in a "derogatory matter" because he was a ticket broker-someone who legally scalped tickets - constituted public accommodations harassment based on "source of income."

- A recent Harvard Law Review Note argues that American Indian team names, including not just the oft-condemned Redskins but also the Braves, Blackhawks, Indians, and Chiefs, are illegal because they create a hostile public accommodations environment. ${ }^{88}$ The U.S. Department of Justice Civil Rights Division likewise began an investigation of a high school whose teams were named the Warriors and the Squaws, on the

84. Maine Hum. Rts. Comm'n regs. ch. 5, pts. II, $\mathrm{III}(\mathrm{C})(1)$, $\mathrm{III}(\mathrm{C})(3)$, available at $<$ ftp://ftp.state.me. us/pub/sos/cec/rcn/apa/94/348/348c005.doc $>$.

85. In re Urban League v. Sambo's, No. 79 PRA 674-06/06 (R.I. Comm'n for Hum. Rts. Mar. 16, 1981). But see Sambo's Restaurants, Inc. v. City of Ann Arbor, 663 F.2d 686 (6th Cir. 1981) (saying that use of Sambo's name was protected by the First Amendment even if it was offensive to black customers); id. at 696 (Keith, J., dissenting) (arguing the contrary); Sambo's v. City Council of City of Toledo, 466 F. Supp. 177 (N.D. Ohio 1979) (holding that it was unconstitutional for a city to deny sign permits to Sambo's because of its name).

86. In re Craig, 1995 WL 907560, at *2, *5-*8 (Chi. Comm'n Hum. Rel. Oct. 18); see also In re Miller, 1998 WL 307868 (Chi. Comm'n Hum. Rel. Apr. 15) (finding racial harassment in public accommodations based on racial epithets during two phone calls made in the context of a dispute over price of plumbing services); In re Ross, 1995 WL 907568 (Chi. Comm'n Hum. Rel. Sept. 20) (finding sexual harassment in public accommodations); Rodger v. Steve's Market, Inc., charge no. PA98-0057 (Vt. Hum. Rts. Comm'n Apr. 14, 1999) (finding disability harassment in public accommodations based on one disability-based insult).

87. In re Plochl, No. 92-PA-46 (Chi. Comm'n Hum. Rel. Oct. 4, 1993). A Chicago city ordinance bans discrimination-and, according to the commission, therefore bans harassment-based on "lawful source of income." Id.; $c f$. CONN. GEN. STAT. ANN. § 46a-64 (likewise banning discrimination in public accommodations based on "lawful source of income"); D.C. CODE. ANN. §1-2519(a) (same); see also N.D. CENT. CODE ch. 14-02.4-14 (same for discrimination based on "status with respect to ... public assistance").

88. Note, A Public Accommodations Challenge to the Use of Indian Team Names and Mascots in Professional Sports, 112 HARV. L. REV. 904 (1999). 
grounds that the district "allow[ed] the use of American Indian religious symbols at [the high school] that demean American Indian religious practices" and that because of the team name classmates would call male students "warriors" and female students "squaws," which created a "racially hostile [educational] environment." Squaws to the presumably less Indian-sounding Lady Warriors.

- Three judges of New York's highest court would have held a gift shop liable under public accommodations law for selling novelty gifts that contained Polish jokes. ${ }^{90}$

- Government agencies have begun to use hostile public accommodations environment law as a tool to try to suppress political speech that they consider improper. Daley Union College in Chicago, for instance, sued a professors' union, claiming that a caustic anti-affirmative-action article in the union newsletter created a "hostile public accommodations environment" at the college; the Chicago Commission on Human Relations rejected the claim, but only on the grounds that a college (unlike a restaurant or a theater) is not a place of public accommodations. ${ }^{91}$ Likewise, the Human Rights Director for the city of St. Paul, Minnesota filed a complaint against the St. Paul Press newspaper claiming that a racially themed cartoon created a hostile public accommodations environment, but eventually dropped it as a result of public pressure. ${ }^{92}$

So far, hostile public accommodations environment claims have been rarer than hostile work environment claims, perhaps because the damages awards available under most public accommodations discrimination laws are much smaller than those available under employment discrimination law. Because the field is still in its infancy, many of the cases involve fact patterns that some agencies might find especially offensive, for instance speech that's said to a particular patron rather than speech aimed at the clientele at large, or speech said by a public accommodation employee rather than by a fellow patron.

But there's no reason to think courts will draw any such distinctions as a matter of law. They do not draw them in hostile work environment harassment law, where speech is punishable even if it's said to a broad audience that includes many willing listeners as well as some unwilling ones, and even if it's said

89. Letter from U.S. Department of Justice, Civil Rights Division, Educational Opportunities Section to Mr. Bob Bowers, Superintendent, Buncombe County Public Schools, Jan. 22, 1999.

90. State Div'n of Human Rights v. McHarris Gift Center, 418 N.E.2d 393 (N.Y. 1980) (Cooke, J., dissenting).

91. In re Board of Trustees and Cook County College Teachers Union, Case No. 97-PA-84, 1999 WL 543884 (Chi. Comm'n Hum. Rel. June 11).

92. See Charge of Discrimination, Terrill v. Saint Paul Pioneer Press, case no. A-3497 (St. Paul. Dep't of Hum. Rts. docketed June 7, 1999); Charles Laszewski, Human Rights Complaint Against Newspaper Appears to Be a First, ST. PAUl PIONEER PRESS, June 11, 1999, at 4D; Charles Laszewski, Terrill Says He Will Drop Newspaper Bias Charge, St. PAUl PIONEER PRESS, June 23, 1999, at 6B. 
by a co-worker rather than by a supervisor. ${ }^{93}$ Nor, as Part III shows, does the government draw such distinctions in hostile educational environment law.

Again, I think that holding ISPs or their users liable for offensive speech generally violates the First Amendment. Here, I can't refer the reader to published constitutional arguments on this topic - to my knowledge, no-one else has written on the free speech issues raised by hostile public accommodations environment law, and my work has only touched on the issue, ${ }^{94}$ still, I hope that many readers will find this conclusion pretty self-evident.

I also hope that this conclusion reinforces the argument that hostile work environment law likewise poses First Amendment problems. Some (though not all) arguments made by defenders of the constitutionality of workplace harassment law would apply equally to validate public accommodations harassment law. Consider, for example, the arguments that harassment law is constitutional because:

(1) speech in private workplaces is already subject to the workplace owner's control and thus the government should also be free to suppress speech in those private workplaces, ${ }^{95}$

(2) harassment law doesn't involve state action because the speech is restricted by the workplace owner, albeit under government pressure $;^{96}$

(3) harassment law is content-neutral under the "secondary effects" doctrine and is thus not subject to strict scrutiny, ${ }^{97}$

(4) harassment law is merely part of a ban on discriminatory conduct and thus isn't really a speech restriction as such $;^{98}$ and

(5) harassment law is constitutional because the First Amendment doesn't protect "invidious private discrimination." "99

All these arguments, if they are valid, could apply equally to public accommodations harassment claims. Either these arguments are sound in both the workplace harassment context and the public accommodations harassment context-

93. Consider the joke e-mail cases, supra text accompanying notes 17-24, and many others.

94. See Volokh, supra note 75, at 414-21, available in updated form at http://www.law.ucla.edu/ faculty/volokh/harass/pubaccom.htm, which documents many of the cases I mention here.

95. See, e.g., Amy Horton, Comment, Of Supervision, Centerfolds, and Censorship: Sexual Harassment, the First Amendment, and the Contours of Title VII, 46 U. MIAMI L. REV. 403, 428-29 (1991).

96. See, e.g., Robinson v. Jacksonville Shipyards, Inc., 760 F. Supp. 1486, 1534 (M.D. Fla. 1991) (making this argument).

97. See id.

98. See id. at 1535; Suzanne G. Lieberman, Recent Development: Current Issues in Sexual Harassment, 50 Wash. U. J. URB. \& CONTEMP. L. 423, 435-36 (1996) ("Proponents of the First Amendment defense to hostile environment sexual harassment claims, however, omit several factors which deserve a place in the analysis. These include the purposes and public policies underlying Title VII, which is to punish discriminatory conduct, not speech.").

99. See the position of the Department of Education's Office for Civil Rights, quoted above in the text accompanying note 59. 
in which case the government may indeed ban offensive speech on America Online-or they are unsound in both contexts.

Moreover, even if hostile public accommodations environment law didn't exist, hostile work environment law would itself restrict speech in places of public accommodation: Most such places, after all, are also someone's workplace.

Consider, for instance, restaurants. A patron wearing a Nazi uniform or a sexually suggestive T-shirt in a restaurant, or making racist or religiously offensive statements to his dinner companions, may well be quite offensive to other patrons. ${ }^{100}$ His speech may create such a "hostile public accommodations environment" that the offended customers may leave the restaurant and feel uncomfortable about ever returning. I hope, though, that most people would agree that the government may not use the threat of legal liability to pressure restaurant owners into banning such offensive speech in their restaurants. Speech in restaurants should be protected against government suppression.

But what if the complaint is brought by an offended waiter, under a workplace harassment theory? Employers, after all, are "responsible for the acts of [patrons]" that create a hostile environment for their employees, where the employer is told of the offensive conduct "and fails to take immediate and appropriate corrective action." from an article in the Society for Human Resource Management's HRMagazine, titled Harassment by Nonemployees: How Should Employers Respond?:

For mild forms of harassment, a polite request, such as simply asking the offending nonemployee to refrain from engaging in the harassing behavior can be used. An employee using this technique might say, "Would you please not tell religious jokes in my presence? I take my religion seriously and don't appreciate the jokes."... [Or] "Would you please not tell ethnic jokes in the presence of our wait staff. Some of them find these jokes offensive. We appreciate your cooperation." ...

[T] he nonemployee harasser [must] be stopped from committing additional harassment, be told that the harassing conduct will not be tolerated, and be warned about sanctions for any future harassing conduct in the workplace. ${ }^{102}$

Good advice as a matter of avoiding employer liability; but it means that, with or without public accommodations harassment law, the government is pressuring employers to impose "sanctions" on people for what they say to their dinner companions in a restaurant. Likewise, with or without educational harassment

100. See Bond v. Michael's Family Restaurant, Wisc. Labor \& Indus. Rev. Comm'n, Case Nos. 9150755, 9151204 (Mar. 30, 1994).

101. 29 C.F.R. $\$ 1604.11(\mathrm{e})$; see also Crist v. Focus Homes, Inc., 122 F.3d 1107 (8th Cir. 1997) (applying this approach); Folkerson v. Circus Circus Enterprises, Inc., 107 F.3d 754 (9th Cir. 1997) (same); David S. Warner, Note, Third-Party Sexual Harassment in the Workplace: An Examination of Client Control, 12 HOFSTRA LAB. L.J. 361 (1995).

102. Diana L. Deadrick et al., Harassment by Nonemployees: How Should Employers Respond?, HRMAGAZINE, Dec. 1, 1996 (written by two management professors and an employment lawyer). 
law, speech on campus that offends employees - such as faculty, teaching assistants, or staff-may lead to workplace harassment liability. ${ }^{103}$

To return to this article's three recurring points: First, whether the government may punish speech that is severe or pervasive enough to create an offensive online environment turns primarily on general free speech doctrine, not on some specific rules of "cyberspace law." True, there are some possible cyberspace-related twists; for instance, cyberspace speech may be read in people's homes, ${ }^{104}$ and not just heard in restaurants, health clubs, or sports arenas. But these shouldn't affect the basic question, which is whether the government may suppress speech that expresses ideas offensive to certain groups in order to make life easier or more equal for members of those groups.

Second, the Clinton Administration is almost entirely absent from these cases. Again we have a body of law that, though ultimately derived from federal employment discrimination precedents, is now enforced by state and local government agencies and private litigants nationwide. The speech restriction will progress with the Administration or without it. Likewise, even if the Administration deliberately decided to refrain from suing based on harassing speech in places of public accommodation, its judgment wouldn't have been terribly influential (though it might have carried some persuasive weight). The influence of the Administration will eventually be felt through the decisions of the judges it appoints, not through its legislative or executive agenda.

Finally, we again see how narrower speech restrictions grow into broader ones. Hostile work environment law leads to hostile educational environment law and then to hostile public accommodation environment law. The slide may not be inevitable: One can imagine courts drawing a line between, say, hostile work environment law on one side and hostile educational and public accommodations environment law on the other. Still, legal analogies have force in a system built on such analogies. So far quite a few agencies have been willing to endorse the broadening of prohibitions on harassing speech; it remains to be seen how many more will join them, and how far the courts will let them go.

\section{$\mathrm{V}$ \\ HARASSMENT BY LIBRARY INTERNET ACCESS}

In 1997, the Loudoun County Public Library made the news by installing filters on all library computers. Such policies are usually justified by the desire to

103. See, e.g., Nat Hentoff, Sexual Harassment by Francisco Goya, WASH. POST, Dec. 27, 1991, at A21 (describing complaint by a Penn State professor that a copy of Goya's painting Naked Maja hanging in her classroom constituted sexual harassment: "'Whether it was a Playboy centerfold or a Goya,' the professor said, 'what I am discussing is that it's a nude picture of a woman which encourages males to make remarks about body parts."'); Nat Hentoff, Trivializing Sexual Harassment, WASH. POST, Jan. 11, 1992, at A19 (reporting that school management took the painting down, citing fear of workplace harassment liability as one reason for its action).

104. See Kavanagh v. Goddard College, charge no. PA99-0002, at 4-5 (Mar. 10, 1999) (discussed supra note 76 and accompanying text). 
block children from accessing sexually explicit material, but here the stated rationale-reflected in the policy's title, Policy on Internet Sexual Harassmentwas quite different:

1. Title VII of the Civil Rights Act prohibits sex discrimination. Library pornography can create a sexually-hostile environment for patrons or staff. .. . Permitting pornographic displays may constitute unlawful sex discrimination in violation of Title VII of the Civil Rights Act. This policy seeks to prevent internet sexual harassment [by installing software that blocks sexually explicit material, including "soft core pornography"].

The policy's author, library trustee (and lawyer) Dick Black, echoed this:

The courts have said, for example, that someone can have materials-racist materials dealing with the Ku Klux Klan-in their home. However, the courts have upheld very strict limitations on having that in the workplace because of the racially discriminatory environment.

Same thing applies here. People can do certain things in the privacy of their own homes that they cannot do in the workplace.

Now this is not limited strictly to libraries. But the courts have said that whether it's a public state facility or whether it's a manufacturing plant, people cannot deprive women of their equal access to those facilities and their equal rights to employment through sexual harassment. ${ }^{106}$

Nor is this an isolated incident; other libraries throughout the country have been doing the same thing, and offering the same justification. ${ }^{107}$ In the words of one article,

105. Loudoun County Public Library, Policy on Internet Sexual Harassment (1997), available at $<$ http://techlawjournal.com/courts/loudon/71020pol.htm $>$.

106. Loudoun County Internet, NPR, Nov. 2, 1997. It's not clear to what extent this policy was primarily motivated by a desire to prevent sexual harassment, and to what extent it was also motivated by a desire to shield children from material seen as inappropriate for them, or even by a desire to generally decrease the distribution of material that some think is immoral and socially harmful. But it seems quite likely that people who generally condemn pornography would also be especially upset by librarians or patrons being involuntarily exposed to the pornography, and the fact that the drafters might have also had other goals in mind is irrelevant. To consider an analogy, many of the architects of harassment law might actually want to suppress pornography, sexist advocacy, and racist advocacy throughout society. See, e.g., CATHERINE MACKInNON, OnLY WORDS (1993); Davis v. Monsanto Chem. Co., 858 F.2d 345, 350 (6th Cir. 1988) ("In essence, while [harassment law] does not require an employer to fire all 'Archie Bunkers' in its employ, the law does require that an employer take prompt action to prevent such bigots from expressing their opinions in a way that abuses or offends their coworkers. By informing people that the expression of racist or sexist attitudes in public is unacceptable, people may eventually learn that such views are undesirable in private, as well. Thus, Title VII may advance the goal of eliminating prejudices and biases in our society."). But these broader social goals of some of the people who support harassment law or library filtering do not by themselves make harassment law or filtering plans unconstitutional. If the display of pornography where others might involuntarily see it, whether in run-of-the-mill workplaces or in libraries, is constitutionally unprotected, then it is generally restrictable regardless of the other goals the restriction might serve.

107. See, e.g., To Filter or Not to Filter: Censorship on the Internet, AM. LIBRARIES, June 16, 1997, at 100 (quoting Austin Public Library Director Brenda Branch) ("As a government official, I am obligated to abide by the law. Cyber Patrol has now been refined to the point where we have found, for the interim, a balance between providing Internet access to adults, protecting minors from pornographic images, and protecting staff from sexual harassment and legal liability."); Marilyn Gell Mason, Sex, Kids, and the Public Library, AM. LIBRARIES, June 16, 1997, at 104 ("Some library users have asked if public viewing of pornography constitutes a new form of sexual harassment."); Sylvia Moreno, Library Censors Internet, DALlAS MORNING NEwS, Mar. 9, 1997, at 46A ("Some library clerks [at the Austin Public Library] said they felt sexually harassed on the job by a patron who spent hours viewing hard- 
[b]lue movie night in the computer lab [where users accessed sexually explicit material online] was not the end of the world as we know it. Left unaddressed, however, it could have become a problem of sexual harassment, with charges that such usage created an uncomfortable situation for many library users-not to mention library staff. Linked to other instances of insensitive, arguably sexist behavior, it could contribute to charges that a hostile environment existed-and could become evidence in a lawsuit.

... Playboy pinups in work areas invite sexual harassment suits. Why should the Internet be any different? ${ }^{108}$

Again we see how some speech restrictions are used as analogies to support other ones, though here the analogy is not from workplaces to colleges or to service providers but the much more direct analogy from "normal" workplaces to libraries as workplaces. "Racist materials dealing with the Ku Klux Klan" are limited in workplaces generally; "same thing applies here" in libraries. Sexually suggestive materials are illegal in "a manufacturing plant"; same goes for libraries. "Playboy pinups in work areas invite sexual harassment suits. Why should the Internet be any different?"

The library case is different in an important way from the other three areas described above. Here, a government agency is acting as proprietor to restrict what is done with its own property, and thus may have far more authority than it would if it were acting as sovereign. ${ }^{109}$ It might be legitimate for the library board members as managers to try to shield library users or employees from involuntary exposure to offensive material, or even to entirely refuse to participate in disseminating material that they think offensive and harmful. Whether a government-owned library may install filters, quite apart from the harassment issues, remains an unsettled matter.

But the harassment question is nonetheless significant, because if libraries must filter to prevent harassment claims, then this rationale extends equally to private libraries and other private Internet access centers. A publicly accessible

core pornography on the computer terminal in direct view of their counter...."); Michael Schuyler, When Does Filtering Turn Into Censorship? Filtering the Internet at Libraries, COMPUTERS IN LIBRARIES, May 1997, at 34 ("This 'inadvertent exposure' is causing a lot of consternation in libraries, including the possibility of sexual harassment suits directed at the institutions because of it."); $c f$. Nick Green, School Board President Rejects Call for Resignation, L.A. TIMES, Oct. 23, 1997, at B6 (describing sexual harassment claim by library employee "based in part on her discovery of the [downloaded sexually explicit] material in a library storeroom").

108. Carol Ebbinghouse \& Robert Giblin, Taming the Wicked, Wicked Net: Acceptable Use and the Internet, SEARCHER, July 17, 1997, at 12 (a magazine for online information brokers). Likewise, as to college libraries and other computer access areas, consider an item quoted above in Part I:

Although a school [in context, referring to colleges and universities] by its very nature must provide for the guarantees of free speech as to classroom expression and assignment, the use of computers, [including] access to the Internet in open computer labs, should be appropriately regulated to avoid a hostile environment for offended students.

Not to take such preventive actions at the work place or school is to place the employer or school at risk.

Powals \& Powals, supra note 34.

109. See, e.g., ISKCON v. Lee, 505 U.S. 672 (1992); Board of Ed. v. Pico, 457 U.S. 853, 863 (1982) (plurality). 
library at Duke University, for instance, would be obligated by state and federal law to install filters to prevent workplace harassment complaints by librarians and public accommodation harassment complaints by patrons; ${ }^{110}$ likewise for an Internet cafe. Here, the government would indeed be acting as sovereign controlling what private institutions do: Even if a private library wanted to provide unlimited access, it would face legal liability for doing so.

Judge Leonie Brinkema's decision in Mainstream Loudoun v. Board of Trustees of the Loudoun County Library ${ }^{111}$ struck an early blow against library Internet filtering. Such filtering, the decision held, violated the First Amendment (at least when it wasn't limited to child-only computers), notwithstanding the potential risk of harassment liability.

One of Judge Brinkema's rationales - that the defendants could point to very few harassment complaints that were brought as a result of patrons accessing sexually explicit materials-isn't promising for the long term, because such complaints are now piling in. For instance, seven librarians recently filed an EEOC complaint based on what they say is "repeated exposure to sexually explicit materials," and an environment "which is increasingly permeated by [pornographic] images on computer screens, [and] is also barraged by hard copies of the same, created on Library provided printers." 112 Forty-seven of the 140 or so library employees signed a letter saying, in response to a library patron's complaint about other patrons accessing sexually explicit material, that "Every day we, too, are subjected to pornography left (sometimes intentionally) on the screens and in the printers. We do not like it either. We feel harassed and intimidated by having to work in a public environment where we might, at any moment, be exposed to degrading or pornographic pictures."113

In response the library enacted a new policy that, among other things, bars even adult patrons from accessing material that is "harmful to minors"-a category of speech that includes material that's constitutionally protected as to adults - and also from otherwise "[e]ngag[ing] in any activity that . . . creates an intimidating or hostile environment." "The Library," the policy says, "is committed to providing its employees and patrons with an environment that is free from all forms of harassment, including sexual harassment, and prohibiting the display of obscene material, child pornography, and material that is harmful to minors." $" 114$

110. Libraries are covered by public accommodation laws. See, e.g., ARIZ. REV. STAT. § 41-1492 subd. 9(h) (West 1999); Colo. ReV. STAT. ANN. § 24-34-601(1) (West 1990); 5 ME. ReV. StAT. ANN. tit. 5, § 4553 subd. 8(H) (West 1999).

111. 24 F. Supp. 2d 552 (E.D. Va. 1998).

112. Charge of Discrimination filed with the EEOC, Adamson v. Minneapolis Public Library; Letter from Robert S. Halagan (plaintiffs' lawyer) to the Minneapolis Public Library, May 2, 2000, at 2.

113. Letters from Readers, STAR TRIB. (Minneapolis), Feb. 12, 2000, at 18A.

114. Minneapolis Public Library, Internet Use Guidelines, Policy \#1130 (adopted May 17, 2000), available at $<\mathrm{http}: / /$ www.mpls.lib.mn.us/policy.htm>; see also Jeremy Olson, Library Sets New Policy for Internet, OMAHA WORLD-HERALD, Mar. 17, 2000, at 15 (describing a public library policy that bans all access to "obscene or sexually explicit materials"); Jeremy Olson, Library May Expand Online Com- 
Nor is the Minneapolis incident an isolated one; librarians in other places have likewise complained about patrons accessing material that they feel is sexually harassing. ${ }^{15}$ Judge Brinkema's argument that "[s]ignificantly, defendant has not pointed to a single incident in which a library employee or patron has complained that material being accessed on the Internet was harassing or created a hostile environment"116 thus seems to be no longer available. If that were the only argument in support of her decision, we would face the specter of harassment law being used to punish private and public libraries and Internet cafes that allow unfiltered access.

The judge's second justification - that the library could avoid harassment liability by placing computers in places where passers-by couldn't routinely see them, or installing privacy screens that make the screen visible only from the place where the user is sitting-seems, however, to be more robust. Such alternative solutions would not be perfect; a library patron may sit down to use a terminal and find that a pornographic site had been left on the screen by a previous patron, ${ }^{117}$ someone who's accessing a pornographic site might have technical trouble and ask a librarian for help, privacy screens may be imperfect, ${ }^{118}$ and patrons or librarians may see offensive material in a printer output bin. ${ }^{119}$ But courts might conclude that these situations are rare enough that when the proper measures are taken, technology does let libraries largely avoid the risk of harassment liability and at the same time provide unfiltered access.

Here, then, might be a case where the speech being in cyberspace does make a difference. To begin with, in the pre-cyberspace world, libraries generally did not stock illustrated pornography. Because buying and shelving books cost money, library decisions not to get a certain book were practically and perhaps even doctrinally immune from review, ${ }^{120}$ and to my knowledge few libraries decided to spend their funds on Hustler. They may have stocked a few "legitimate" books that included sexually explicit pictures, and it was possible that a

puter Time, OMAHA WORLD-HERALD, Mar. 15, 2000, at 15 (citing concerns about "a 'sexual harassment' situation for librarians who work with the computers and may be exposed to those images" as part of the reason for policy).

115. See, e.g., Ann Donnelly, Porn Access Unbearable for Some on Library Staff, THE COLUMBIAN, July 26, 1998, at B13; see also David Burt (of the Family Research Council), Dangerous Access, 2000 Edition: Uncovering Internet Pornography in America's Libraries, at 17-19 (reporting several such complaints), available at $<\mathrm{http}: / / \mathrm{www}$.frc.org/misc/bl063.pdf $>$. David Burt is a partisan in these debates, but I have no reason to doubt that the people whom he quotes were indeed genuinely offended by being involuntarily exposed to sexually themed material.

116. 24 F. Supp. $2 d$ at 556.

117. This risk might be diminished, though not eliminated, by having the computer reset itself when it has been idle for a certain length of time.

118. "The black polarized privacy screens on some library computers don't prevent anyone directly in front of the computer from catching a full view." Paul Levy, Cyberporn Poses Tough Questions for Libraries, STAR TRIB. (Minneapolis), Feb. 22, 2000, at 1A.

119. See Charge of Discrimination, supra note 112.

120. See Board of Ed. v. Pico, 457 U.S. 853, 862, 871-72 (1982) (plurality) (acknowledging that the Court's holding, which limited the power of libraries to remove books from the shelves, might not apply to decisions not to buy the books to begin with). 
patron might leave such a book open on the table, but I suspect this happened quite rarely.

The "hostile environment" concern arose largely because libraries that provide Internet access need not decide on an item-by-item basis what cyberspace material to "stock" and what not to stock. Pornography is thus by default included in any Internet-connected library's "cyber-collection," which means that most libraries now for the first time face the prospect of being major access points for pornography. And this factual change also potentially changes the doctrinal question: The Pico plurality drew a distinction between "choos[ing] [which] books to add to the libraries" and "discretion to remove books," while refusal to buy Hustler falls in the first category, the decision to block the Hustler site seems to fall in the second.

On the other side of the ledger, computer technology makes it easier to decrease the risk that offended patrons or librarians will inadvertently see offensive material. Privacy screens on computers generally ensure that casual passers-by won't see what's going on. Any attempts to control offensive print materials (once the library had bought them) would probably be much less effective.

The Clinton Administration has been involved in two ways in library cyberspace issues. The first, and fairly slight, involvement is quite recent, and limited to the question of shielding children rather than protecting potentially offended bystanders. The Communications Act of 1996 authorizes the Federal Communication Commission to give subsidies to public schools and libraries for wiring and for discounted Internet connections, and a pending bill in Congress would require that subsidy recipients install filtering software. ${ }^{122}$ In April 1999, the Department of Commerce urged the FCC to take a different view:

$[\mathrm{T}]$ he federal government should not require that schools and libraries adopt any particular type of technology such as filtering or blocking, but rather adopt "user policies" that offer parents reasonable assurances that safeguards will be in place that permit them to have educational experiences consistent with their values when using the Internet. $^{123}$

How exactly these "user policies" are to be enforced is unclear, but at least the Administration seems to think the federal government should not be requiring filters.

The second involvement is much more important, though doubtless not explicitly planned by the Administration. In 1993, President Clinton, on the advice of Democratic Senator Charles Robb, appointed Judge Brinkema to the

121. Id. at 871 .

122. See H.R. 896 and S. 97, 106th Cong., 1st Sess.

123. Commerce Urges FCC to Require Schools to Adopt User Policy to Safeguard Children Using the Internet, U.S. DEP'T OF COMMERCE NEWS, Apr. 8, 1999, available at <http://www.ntia.doc.gov/ ntiahome/press/erateaupr.htm> (visited Mar. 4, 2000); Letter from Assistant Secretary of Commerce Larry Irving to FCC Chairman William E. Kennard, Apr. 8, 1999, available at $<$ http://www.ntia.doc.gov/ntiahome/ fccfilings/acceptableuseltr.htm> (visited Mar. 4, 2000). 
federal district court. ${ }^{124}$ Judge Brinkema's Loudoun opinion has been very influential. ${ }^{125}$ Newspapers have widely reported it, it is the only opinion that has been published on this subject, and the Library Board decided not to appeal it. ${ }^{126}$ Of course, the opinion is not binding precedent for other libraries, but its existence is a powerful political and prudential argument against libraries implementing similarly broad filtering software. Since the decision, the antipornography forces seem to have shifted primarily (though not entirely, as the Minneapolis incident shows) to asking for filtering on library computers used by children, a policy whose constitutionality Judge Brinkema's opinion didn't resolve.

The Loudoun case was genuinely close; it's quite plausible to argue that the government acting as library manager should have considerable power to select what to allow inside the library. A different judge may have decided the matter quite differently, and the precedent would have come out the other way. Such a pro-filtering decision would probably have been appealed-the opponents of filtering policies seem more aggressive in this respect than pro-filtering libraries are-so eventually there would have been at least a few court of appeals cases on the subject, rather than a single district judge's decision. Still, the ultimate result might have been different.

Finally, here we see a judge stopping or at least delaying the expansion of harassment law, though based on a peculiar factual circumstance: the technical ease, not present in most cases, of protecting speech while at the same time largely preventing harassment claims. ${ }^{127}$ What the result would have been in a different situation-for instance, given a harassment claim brought by a patron or a librarian based on a painting of a nude displayed in a private library foyer-is hard to tell. ${ }^{128}$ (This hypothetical is hardly implausible, as the incidents

124. See Kent Jenkins Jr. \& Charles W. Hall, Robb Picks Women for Legal Posts; 2 From N. Va. Tapped For Prosecutor, Judge, WASH. Post, May 25, 1993, at C1. Judge Brinkema had been a magistrate judge in that court for seven years, but magistrate judges have only derivative authority, and are appointed by the district court, not the President. See 28 U.S.C. $§ 631$ (1994).

125. See Mainstream Loudoun v. Board of Trustees of the Loudoun County Library, 24 F. Supp. 2d 552 (E.D. Va. 1998).

126. See Dana Hedgpeth, Libraries Abandon Court Fight; Board Won't Appeal Internet Policy Rulings, WASH. POST, Apr. 22, 1999, at V03.

127. Note that this may not be an option in the traditional employment context I describe in Part I. Privacy screens may make it impossible for people to show material on their computers to coworkers-something that many employees sometimes have to do as part of their jobs (if only to show technical support a problem that they're encountering when using the computer). Likewise, office layouts may prevent many computer screens from being reoriented to prevent passers-by from seeing them.

128. The judge did not rest her decision on the theory-which some people have urged-that libraries are somehow different from other workplaces (because they are somehow more devoted to First Amendment activities), and that speech which may be actionable sexual harassment in other places is not actionable in libraries. In any event, such a distinction would probably not work: One cannot say that librarians have "assumed the risk" of encountering offensive material by going to work in a library, because the right to be free from sexual harassment can't be waived this way, see Alexander v. Gardner-Denver Co., 415 U.S. 36, 51 (1974) (noting that "[t]here can be no prospective waiver of 


\section{cited below show. ${ }^{129}$ ) But at least the decision gives reason to hope that harass- ment claims will not prove to be a universal solvent of free speech.}

an employee's rights under Title VII"), and many librarians started working long before libraries started providing Internet access and thus created the risk of exposure to Internet pornography.

129. See, e.g., supra note 103 (discussing the complaint brought based on a copy of Goya's Naked Maja hanging in a classroom); Vogel, Kelly, Knutson, Weir, Bye \& Hunke, Ltd. [a law firm], Political Correctness Gone Too Far or Serious Concern for Employers?, NORTH DAKOTA EMP. LAW LETTER, Nov. 1997 ("[T]he Goya incident illustrates that workplace conduct—and, yes, even paintings—-that once may have been considered acceptable may no longer be"; this is said in an article aimed at "provid[ing] a basic definition of sexual harassment and outlin[ing] steps employers can take to prevent harassment in the workplace and avoid liability if harassment occurs."); Memorandum from Mary Harding, Affirmative Action Officer, Lower Columbia College, Sept. 25, 1995:

During the past few months, complaints have been filed with me regarding various forms of art posted on campus and the sexual harassment felt by members of the campus community when they view the art. In order to provide a work and learning atmosphere free from harassment and intimidation, and to protect the college and all employees from costly legal defense resulting from sexual harassment and discrimination claims, I remind you that it is college policy that employees and students shall be provided a place to work and study that is absent an intimidating, hostile, or offensive environment. ... Staff members and students will be expected to comply with [the affirmative action officer's] request or with the president's decision regarding removal of bothersome pieces of art in the interest of protecting the college and the accused employee or student from claims of discrimination and harassment, and in the interest of providing a harassment-free working and learning environment.

Likewise, when a City Hall employee in Murfreesboro, Tennessee complained about an impressionist painting hanging in a hallway depicting a partly naked woman, the City Attorney had it taken down, saying,

I feel more comfortable siding with protecting the rights under the Title VII sexual harassment statutes than ... under the First Amendment.... We wouldn't permit that type of drawing or picture to hang in the fire hall. As far as I'm concerned, a naked woman is a naked woman....

Jennifer Goode, It's Art vs. Sexual Harassment, TennEsSEAN, Mar. 1, 1996, at 1A.

Though [the complainant] probably couldn't win a sexual harassment suit over the picture, Murfreesboro still has to protect itself against future lawsuits, [the City Attorney] said. If the city did nothing about the complaint about [the painting] or other complaints of harassment, a court could conclude the city was ignoring the rights of its female employees.

Catherine Trevison, Court to Decide if Nude Is Naughty, TENNESSEAN, Feb. 13, 1997, at 1B. See Eugene Volokh, Thinking Ahead About Freedom of Speech and Hostile Work Environment Harassment, 17 BERKELEY J. EMP. LABOR L. 305, 304 (1996), or <http://www.law.ucla.edu/faculty/volokh/ harass/data/painting.htm>, for a photograph of the painting. A federal district court held that the government's taking down the painting violated the First Amendment, Henderson v. City of Murfreesboro, 960 F. Supp. 1292 (M.D. Tenn. 1997), but the city attorney's response to that judgment is instructive:

"Sexual harassment is a very dangerous area for any employer today. You really can't be too cautious," [City Attorney Thomas L.] Reed said. "This judgment was for $\$ 1$ and costs. A sexual harassment judgment usually has six zeros behind it. Quite frankly, I'm an advocate of the First Amendment, but a very conservative lawyer when it comes to giving advice."

Sharon H. Fitzgerald, Free Speech Wins, TenNESSEE Town \& CITY, Apr. 14, 1997, at 1; see also PeOPle for the AMERICAN WAY, ARTistic FreEdom Under ATTACK 29, 50, 92, 156, 214, 221 (1994) (listing eight other instances where employees claimed that public art involving nudity constituted workplace harassment; in each case the work was taken down-most employers would much rather do this than litigate- - though in two instances it was later reinstalled); see also id. at 111, 208 (describing two more incidents, in which the complaints did not specifically refer to harassment but city officials nonetheless concluded that the work might be harassing); L.A. TIMES, Oct. 31, 1986, § 1, at 2 (describing how Los Angeles county officials objected that a sculpture of a naked man displayed in the County Hall of Justice and Records "might interfere with programs on sexual harassment," and asked the county Arts Council to cover it); Art of Birth Raises Hackles, VANCOUVER Sun, May 25, 1992 (describing how critics condemned as "a form of sexual harassment" a painting in a city hill gallery depicting a woman who symbolizes Mother Earth giving birth to a child poisoned by chemicals); Mont. Hum. 


\section{CONCLUSION}

Forty years after the end of the Eisenhower Administration, what can we say about how it affected the freedom of speech? Not that much, probably, except of course for the way the Eisenhower appointees to the Supreme Court (and perhaps to lower courts) affected Free Speech Clause case law. Free speech concepts may have changed during the Eisenhower years, but little of that change comes from the legislative or executive agenda of the Eisenhower White House. This is true of many presidencies, and it will probably be true of the Clinton Administration.

Likewise, what can we say now about freedom of speech in movies, on telephones, via faxes, on television, in cyberspace, and in other media? By and large, the answer is that free speech jurisprudence has evolved to be comparatively medium-independent. Early holdings that movies are constitutionally unprotected have been reversed..$^{130}$ In its very first cyberspace case, the Court refused to create a medium-specific test. ${ }^{131}$ While broadcast television and radio are still subject to different rules than other media, even this traditional distinction is now somewhat precarious. ${ }^{132}$ Medium does matter with regard to content-neutral distinctions that are justified by noncommunicative concerns, because different media raise different noncommunicative concerns-soundtrucks are loud, billboards block the view, cable television systems are often monopolies. As to content-based distinctions, though, medium is not terribly relevant.

Rts. Comm'n, Model Equal Employment Opportunity Policy: A Guide for Employers (no date) ("Examples of prohibited sexual harassment include, but are not limited to: ... . Displays of magazines, books, or pictures with a sexual connotation"); Nat Hentoff, $A$ "Pinup" of His Wife, WASH. POST, June 5, 1993, at A21 (describing how a harassment complaint was filed at the University of Nebraska at Lincoln against a graduate student who had on his desk a 5" x 7" photograph of his wife in a bikini; the employer ordered that the photo be removed).

Of course all this is only to be expected. When the law tries to root out "pornography," especially using a definition as vague as "speech severe or pervasive enough to create a hostile or offensive environment for a reasonable person based on sex," attacks on legitimate art are sure to follow. Finally, note that harassment law's ban of sexually suggestive materials is not at all limited to nudity. See, e.g., In re Grievance of Butler, 697 A.2d 659, 664 (Vt. 1997) (concluding that "a poster ... of a woman in a skimpy bikini" could count as harassment, because "the posting or display of any sexually oriented materials in common areas that tend to denigrate or depict women as sexual objects may serve as evidence of a hostile environment").

130. See Joseph Burstyn, Inc. v. Wilson, 343 U.S. 495 (1952), rev'g Mutual Film Corp. v. Industrial Comm'n, 236 U.S. 230 (1915).

131. See Reno v. ACLU, 521 U.S. 844 (1997).

132. See, e.g., Turner Broadcasting Sys., Inc. v. FCC, 512 U.S. 622, 637-38 (1994) (referring to "the rationale for applying a less rigorous standard of First Amendment scrutiny to broadcast regulation, whatever its validity in the cases elaborating it," acknowledging that "courts and commentators have criticized the scarcity rationale," and declining to extend it to cable television). Compare Denver Area Educ. Telecom. Consortium v. FCC, 518 U.S. 727 (1996) (plurality) (upholding a cable television speech restriction by analogy to FCC v. Pacifica Foundation, 438 U.S. 726 (1978), a case that rests on the special character of over-the-air broadcasting) with id. at 805 (Kennedy, J., joined by Ginsburg, J., concurring in part and dissenting in part) (insisting that strict scrutiny, not the lower standard applicable to over-the-air broadcasting, ought to be applied) and id. at 813 (Thomas, J., joined by Scalia, J., and Rehnquist, C.J., concurring in part and dissenting in part) (same). 
But the basic concepts underlying the free speech exceptions remain important for decades. For instance, incitement, bad tendency, commercial speech, obscenity, libel, and now speech that creates a hostile environment are powerful concepts that can mold free speech thinking over a wide range of cases. Some of these free speech exceptions are eventually discarded (for instance, bad tendency). Others are changed (commercial speech, obscenity, libel), though many of the principles underlying them remain. Still others, such as "speech that creates a hostile environment," spread from their roots in narrow situations where they seem proper and even morally imperative into considerably broader areas, and can provide indirect precedential support for even broader restrictions.

Free speech law certainly must recognize exceptions to the core First Amendment principle that the government acting as sovereign generally may not restrict speech because of its content. But before endorsing any such exception, we should consider it carefully, and try to come up with principles that can limit its scope. The risk of speech restrictions growing by analogy in a legal system built on analogy is very real. And so far, the harassing speech exception has not gotten the judicial and academic scrutiny that it deserves, and that is needed to properly cabin the exception and to prevent its unchecked growth. 